\title{
Post-irradiation Examination Plan for ORNL and University of California Santa Barbara Assessment of UCSB ATR-2 Irradiation Experiment
}

\section{December 2013}

Prepared by

R. K. Nanstad ${ }^{1}$, G. R. Odette ${ }^{2}$, T. Yamamoto ${ }^{2}$ and M. A. Sokolov ${ }^{1}$, ${ }^{1}$ Materials Science and Technology Division, Oak Ridge National Laboratory

${ }^{2}$ University of California Santa Barbara

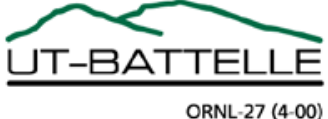


This report was prepared as an account of work sponsored by an agency of the United States Government. Neither the United States Government nor any agency thereof, nor any of their employees, makes any warranty, express or implied, or assumes any legal liability or responsibility for the accuracy, completeness, or usefulness of any information, apparatus, product, or process disclosed, or represents that its use would not infringe privately owned rights. Reference herein to any specific commercial product, process, or service by trade name, trademark, manufacturer, or otherwise, does not necessarily constitute or imply its endorsement, recommendation, or favoring by the United States Government or any agency thereof. The views and opinions of authors expressed herein do not necessarily state or reflect those of the United States Government or any agency thereof. 
This page intentionally left blank 
Light Water Reactor Sustainability

\title{
Post-irradiation Examination Plan for ORNL and University of California Santa Barbara Assessment of UCSB ATR-2 Irradiation Experiment
}

\author{
R. K. Nanstad ${ }^{1}$, G. R. Odette ${ }^{2}$, T. Yamamoto ${ }^{2}$ and M. A. Sokolov ${ }^{1}$, \\ ${ }^{1}$ Materials Science and Technology Division, Oak Ridge National Laboratory \\ ${ }^{2}$ University of California Santa Barbara
}

Date Published: December 2013

Prepared under the direction of the

U.S. Department of Energy

Office of Nuclear Energy

Light Water Reactor Sustainability

Materials Aging and Degradation Pathway

Prepared by

OAK RIDGE NATIONAL LABORATORY

Oak Ridge, Tennessee 37831-6283

managed by

UT-BATTELLE, LLC

for the

U.S. DEPARTMENT OF ENERGY

under contract DE-AC05-00OR22725 
This page intentionally left blank 


\section{CONTENTS}

\section{Page}

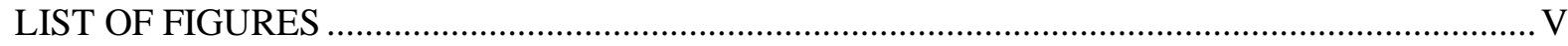

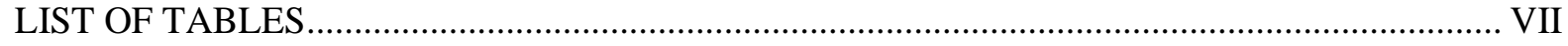

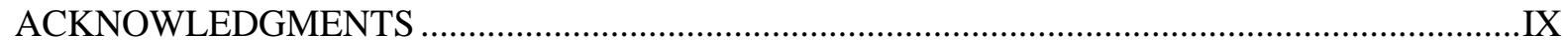

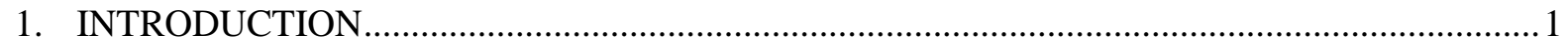

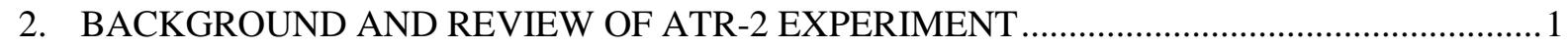

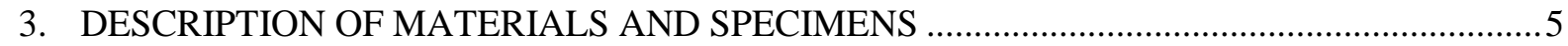

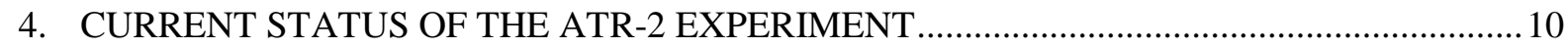

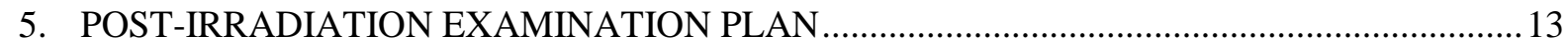

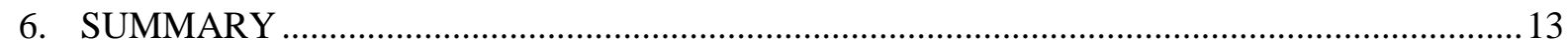

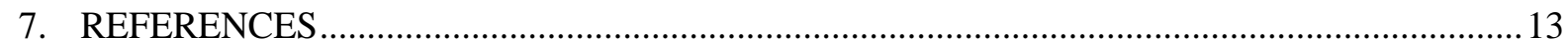

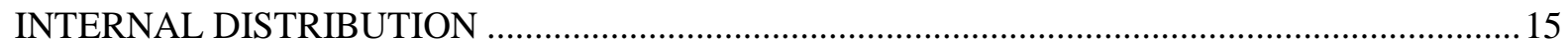

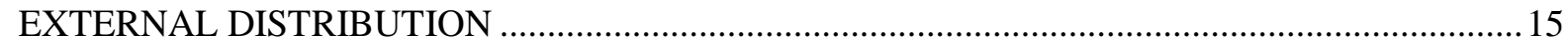

APPENDIX A - UCSB ATR-2 MATERIAL KEY SUMMARY ….............................................13

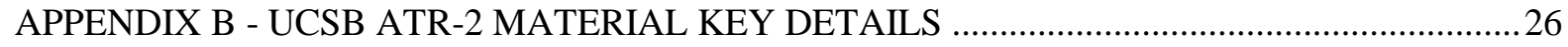

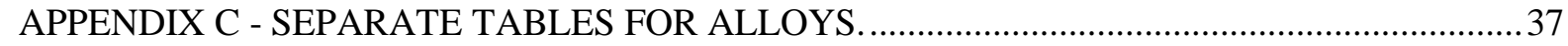

APPENDIX D - PRELIMINARY SCHEDULE FOR PIE OF ATR-2 EXPERIMENT.....................47 
This page intentionally left blank 


\section{LIST OF FIGURES}

Figure

Page

2.1 Schematic depiction of the flux/fluence range for the ATR-2 experiment, showing overlap of existing data from the IVAR and REVE databases...

2.2 Capsule layout relative to the specimen temperature and to the flux/fluence level. The numbers on the left, 1-13, refer to the sub-capsules described in Table 2.1....................... 4

3.1 Schematic figure of multi-purpose disc specimen with diameter and thickness indicated..

3.2 Schematic diagram showing concept for loading of multi-purpose disc specimens, Bettis coupons, and dosimetry wire cannisters into the sub-capsule

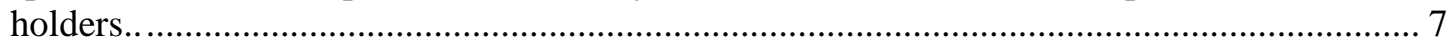

3.3 Schematic diagram showing concept for loading of tensile specimen into sub-

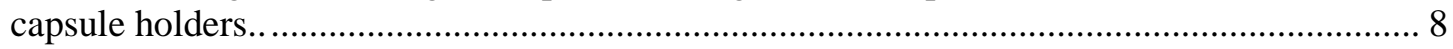

3.4 Yield strength from tensile specimens vs shear punch tests indicating an

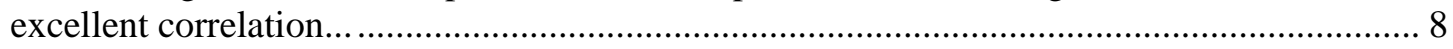

3.5 Schematic diagram showing disc compact specimen design and holder for loading specimens into sub-capsules... 9

3.6 Stand-alone apparatus designed by UCSB for shear punch testing of the multipurpose disc specimens..

3.7 Schematic drawing of diffusion-multiple specimen, with high purity $\mathrm{Cu}$ and $\mathrm{Ni}$ embedded in a larger disc (UCSB Alloy OV1, an Fe/1.6Mn alloy)... 
This page intentionally left blank 


\section{LIST OF TABLES}

\section{Table}

Page

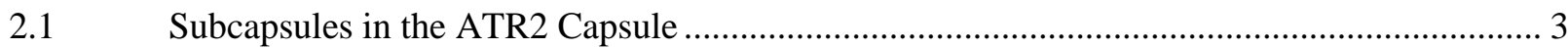

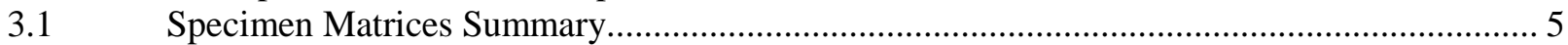

3.2 List of archival surveillance materials supplied by Westinghouse and Florida

Power and Light for the ATR-2 experiment.. 6 
This page intentionally left blank 


\section{ACKNOWLEDGMENTS}

This research was sponsored by the U.S. Department of Energy, Office of Nuclear Energy, for the Light Water Reactor Sustainability (LWRS) Research and Development effort as well as the ATR National Scientific Users Facility (NSUF) that supported the irradiation experiment. The authors specifically extend their appreciation to Dr. Jeremy Busby for LWRS programmatic support, and to Dr. Xiang (Frank) Chen for technical review. We also specifically acknowledge the major NSUF contributions of Jim Cole, Brandon Miller, Collin Knight, Paul Murray, Joe Nielsen, Mitch Meyer, Mike Sprenger, Tom Maddock and other ATR National Scientific User Facility staff for conducting the UCSB ATR-2 irradiation. 
This page intentionally left blank 


\section{INTRODUCTION}

The reactor pressure vessel (RPV) in a light-water reactor (LWR) represents the first line of defense against a release of radiation in case of an accident. Thus, regulations that govern the operation of commercial nuclear power plants require conservative margins of fracture toughness, both during normal operation and under accident scenarios. In the unirradiated condition, the RPV has sufficient fracture toughness such that failure is implausible under any postulated condition, including pressurized thermal shock (PTS) in pressurized water reactors (PWR). In the irradiated condition, however, the fracture toughness of the RPV may be severely degraded, with the degree of toughness loss dependent on the radiation sensitivity of the materials. As stated in previous progress reports, the available embrittlement predictive models, e.g. [1], and our present understanding of radiation damage are not fully quantitative, and do not treat all potentially significant variables and issues, particularly considering extension of operation to 80y.

The major issues regarding irradiation effects are discussed in [2, 3] and have also been discussed in previous progress and milestone reports. As noted previously, of the many significant issues discussed, the issue considered to have the most impact on the current regulatory process is that associated with effects of neutron irradiation on RPV steels at high fluence, for long irradiation times, and as affected by neutron flux. It is clear that embrittlement of RPV steels is a critical issue that may limit LWR plant life extension. The primary objective of the LWRSP RPV task is to develop robust predictions of transition temperature shifts (TTS) at high fluence ( $\phi \mathrm{t})$ to at least $10^{20} \mathrm{n} / \mathrm{cm}^{2}(>1 \mathrm{MeV})$ pertinent to plant operation of some pressurized water reactors (PWR) for 80 full power years. Correlations between the high flux test reactor results and low flux surveillance specimens must be established for proper RPV embrittlement predictions of the current nuclear power fleet. Additionally, a complete understanding of defect evolution for high nickel RPV steels is needed to characterize the embrittlement potential of Mn-Ni-enriched precipitates (MNPs), particularly for the high fluence regime. While understanding of copper-enriched precipitates (CRPs) have been fully developed, the discovery and experimental verification [4,5] of 'late blooming' MNPs with little to no copper for nucleation has stimulated research efforts to understand the evolution of these phases. New and existing databases will be combined to support development of physically based models of TTS for high fluence-low flux $\left(\phi<10^{11} \mathrm{n} / \mathrm{cm}^{2}\right.$-s) conditions, beyond the existing surveillance database, to neutron fluences of at least $1 \times 10^{20} \mathrm{n} / \mathrm{cm}^{2}(>1 \mathrm{MeV})$. All references to neutron flux and fluence in this report are for fast neutrons $(>1 \mathrm{MeV})$.

The RPV task of the LWRS Program is working with various organizations to obtain archival surveillance materials from commercial nuclear power plants to allow for comparisons of the irradiation-induced microstructural features from reactor surveillance materials with those from similar materials irradiated under high flux conditions in test reactors, such as the UCSB ATR-2 experiment. This report is submitted relative to the Level 3 Milestone M3LW-14OR0402012 "Complete report on post-irradiation examination plan for ORNL and University of California Santa Barbara assessment of ATR-2 capsules.”

\section{BACKGROUND AND REVIEW OF ATR-2 EXPERIMENT}

To obtain high fluence data in a reasonable time (e.g., one or two years), test reactor experiments must be performed in such a way to enable development of a mechanistic understanding of the effects of flux [2,3]. As described previously, such an irradiation experiment is currently underway as part of the Idaho National Laboratory (INL) Advanced Test Reactor (ATR) National Scientific User Facility (NSUF). The experiment was awarded to University of California, Santa Barbara (UCSB) and its collaborator, ORNL, several years ago with full funding for the facility provided by DOE through the NSUF. A description of the UCSB ATR-2 experiment and materials 
was provided in previous progress reports [5] and will be summarized briefly here.

In collaboration with UCSB the INL staff carried out conceptual design of the sophisticated instrumented irradiation test assembly (capsule). The INL staff carried out the engineering design, construction and insertion of the test assembly, and is currently responsible for operation of the UCSB ATR-2 irradiation experiment. The scientific experiment itself was designed by UCSB in collaboration with ORNL. The total of 173 alloys included in the experiment were acquired by UCSB and ORNL, including those contributed by Rolls Royce Marine (UK), Bettis Atomic Power Laboratory (US), and the Central Research Institute for the Electric Power Industry (Japan). Notably, the Rolls Royce contribution included a total of more than 50 new alloys. Additionally, surveillance materials from various operating nuclear reactors are included to enable a direct comparison of results from a test reactor at high flux and a power reactor at low flux. The specific surveillance materials were described in detail in [5, 6] and are summarized in Section 3 of this report. Fabrication of the specimens was primarily carried out by UCSB with the assistance of ORNL. The specimens were loaded into thin walled cups at UCSB and the cups were loaded into the test assembly at INL.

The irradiation is being carried out in the so-called "Small I" position in ATR just inside the pressure vessel and reflector. The test assembly has a $20 \mathrm{~mm}$ inside diameter and is $\approx 1.2 \mathrm{~m}$ long. The UCSB ATR-2 experiment includes 1664 small specimens in three basic geometries. These include (1) tensile specimens, for a large matrix of alloys; (2) so-called multipurpose disc coupons that will support microhardness, shear punch and a wide variety of microstructural characterization studies (e.g., small-angle neutron scattering, atom probe, etc) for all the alloys; (3) 20-mm diameter disc compact tension (DCT) fracture specimens for three alloys - the Palisades B weld and two UCSB forgings (C17 and LP). The DCT specimens are being irradiated at a nominal temperature of $290^{\circ} \mathrm{C}$. The test assembly includes a gadolinium thermal neutron shield and active temperature control with three major regions at nominal temperatures of 270,290 and $310^{\circ} \mathrm{C}$, and one small region at $250^{\circ} \mathrm{C}$. The specimens are being irradiated at a peak flux of about $3.3 \times 10^{12} \mathrm{n} / \mathrm{cm}^{2}-\mathrm{s}(>1 \mathrm{MeV})$ to a target fluence of $1 \times 10^{20} \mathrm{n} / \mathrm{cm}^{2}$. The objective is to obtain a high f1uence, intermediate flux database to couple to a large body of existing data for a large set of common alloys $(\geq 100)$ irradiated over a wide range of flux and fluence. Figure 2.1 shows the flux/fluence range for the ATR-2 experiment (red line). The results from the experiment will allow for direct comparisons with two existing test reactor databases (IVAR and REVE, shown in filled triangles and circles, respectively).

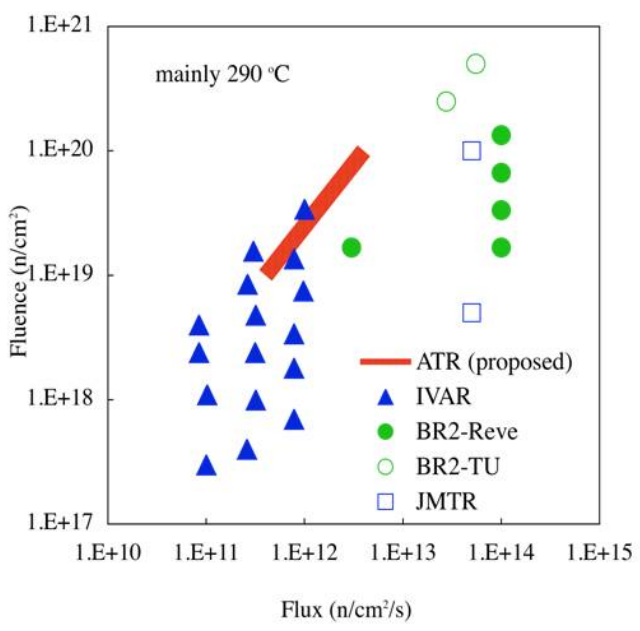

Figure 2.1. Schematic depiction of the flux/fluence range for the ATR-2 experiment, showing overlap of existing data from the IVAR and REVE databases. 
Table 2.1 provides the identification, general specimen types, target irradiation temperature, and nominal target fluence ( $\phi \mathrm{t})$ for each of the 13 sub-capsules included in the ATR-2 capsule, while Figure 2.2 shows the capsule layout relative to the specimen temperature and to the flux/fluence level normalized to the peak value of 1 on the abscissa. Relative to the peak flux/fluence of 1 at the center position of the capsule (zero on the ordinate), the sub-capsules near the ends of the capsule (i.e., at about +550 and $-550 \mathrm{~mm}$ ) will achieve a flux/fluence from about 35 to $45 \%$ of the peak value.

Table 2.1. Subcapsules in the ATR2 Capsule.

\begin{tabular}{|c|c|c|c|}
\hline Capsule ID & Materials & Target Temp. & $\begin{array}{c}\text { Nominal Target } \square \mathrm{t} \\
\left(\mathrm{x} 10^{19} \mathrm{n} / \mathrm{cm}^{2}\right)\end{array}$ \\
\hline UCSB-1 & coupon/tensile & $290^{\circ} \mathrm{C}$ & low 4.2 \\
\hline UCSB-2 & coupon/tensile & $290^{\circ} \mathrm{C}$ & low 6.2 \\
\hline UCSB-3 & coupon/tensile & $290^{\circ} \mathrm{C}$ & med 8.8 \\
\hline UCSB-4 & coupon/tensile & $270{ }^{\circ} \mathrm{C}$ & med 10.3 \\
\hline UCSB-5 & coupon/tensile & $250^{\circ} \mathrm{C}$ & med/hi 10.9 \\
\hline UCSB-6 & DCT & $290^{\circ} \mathrm{C}$ & hi 11.7 \\
\hline UCSB-7 & coupon/tensile & $290^{\circ} \mathrm{C}$ & hi 12.2 \\
\hline UCSB-8 & coupon/tensile & $290^{\circ} \mathrm{C}$ & hi 12.3 \\
\hline UCSB-9 & DCT & $290^{\circ} \mathrm{C}$ & hi 11.7 \\
\hline UCSB-10 coupon/tensile & $310^{\circ} \mathrm{C}$ & med/hi 11.0 \\
\hline UCSB-11 coupon/tensile & $290^{\circ} \mathrm{C}$ & med 9.8 \\
\hline UCSB-12 & DCT & $290^{\circ} \mathrm{C}$ & low 7.6 \\
\hline UCSB-13 coupon/tensile & $290^{\circ} \mathrm{C}$ & low 5.5 \\
\hline
\end{tabular}

Thus, a variety of relatively small specimens of many different RPV steels have been incorporated, including many materials that have been irradiated and tested in previous test reactor programs at different flux levels. The materials in the ATR-2 capsule are described in greater detail in Section 3. 
ORNL/TM-2013/598

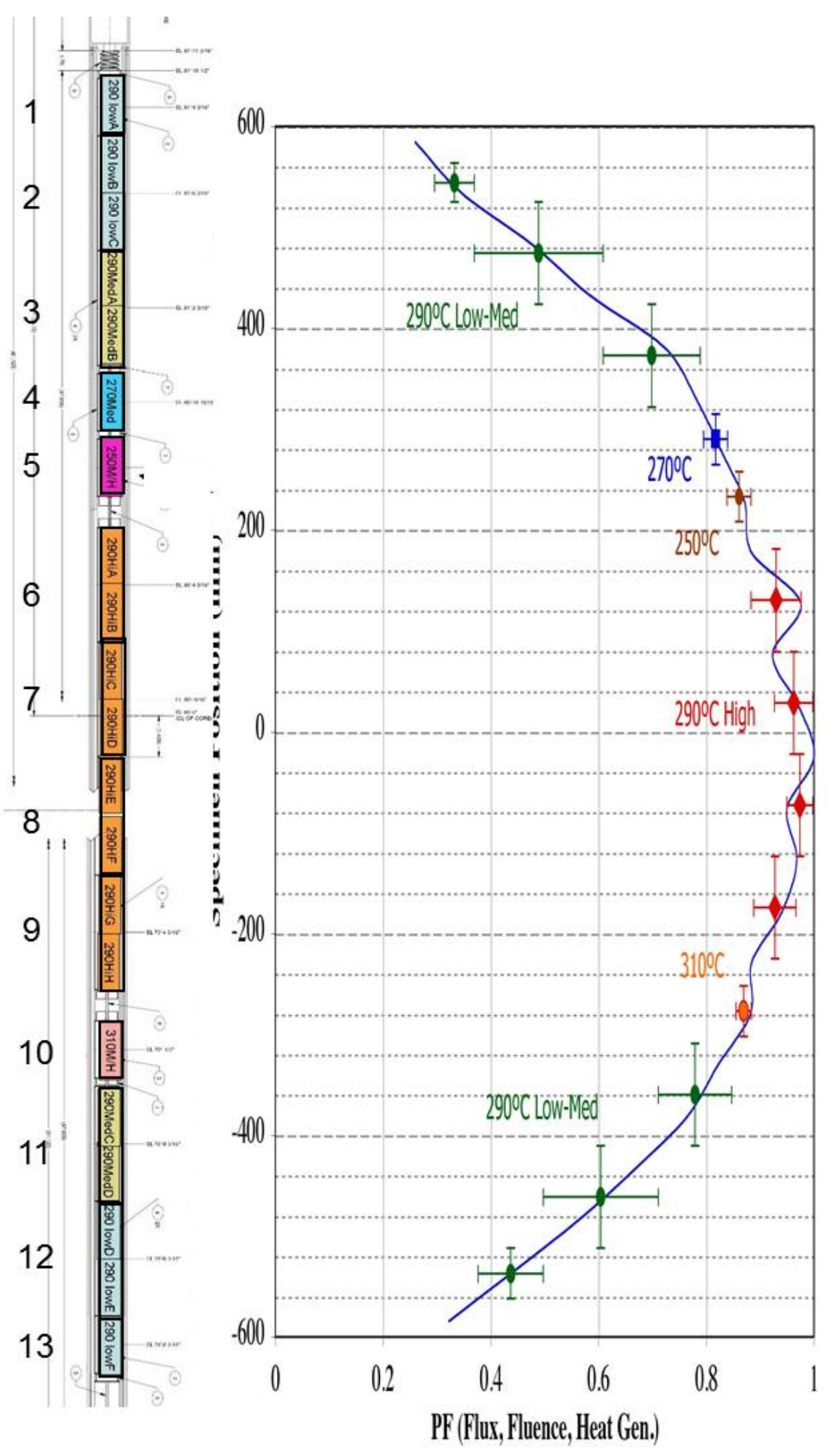

Figure 2.2 Capsule layout relative to the specimen temperature and to the flux/fluence level. The numbers on the left, 1-13, refer to the sub-capsules described in Table 2.1. 


\section{DESCRIPTION OF MATERIALS AND SPECIMENS}

A summary of the materials, specimen types and numbers is provided in Table 3.1. As mentioned earlier, 173 alloys with 1664 specimens are included in the capsule. The DCT matrix includes three alloys, the Palisades B weld and two UCSB forgings (C17 and LP), while the UCSB commercial alloys include HSST Plate 02, HSSI Weld 73W, Midland Beltline Weld (WF-70), and other alloys from the UCSB IVAR project, etc. Additionally, surveillance materials from various operating nuclear reactors, designated ORNL alloys in Table 3.1, are included to enable a direct comparison of results from a test reactor at high flux and power reactors at low fluxes. A variety of surveillance materials were identified as those that would provide results of particular interest to the ATR-2 experimental objectives. These materials were identified based not only on their chemical composition but also on their inclusion in capsules intended for relatively high fluence to allow for comparisons of results from surveillance conditions and the test reactor conditions in the ATR-2 and subsequent experiments. From the group of materials identified as potential candidates, and with the major assistance of ATI-Consulting, we were able to procure nine specific RPV surveillance materials for inclusion in the ATR-2 capsule and they are shown in Table 3.2 below.

Table 3. 1 Specimen Matrices Summary

\begin{tabular}{|c|c|c|c|c|c|c|c|c|c|c|}
\hline & \multicolumn{2}{|c|}{ Lg Disc } & \multicolumn{2}{|c|}{ Sm Disc } & \multicolumn{2}{|c|}{ Tens } & \multicolumn{2}{|c|}{ DCT } & \multicolumn{2}{|c|}{ Any Type } \\
\hline Total \# alloy/irrad cond & Alloy & Spc. & Alloy & Spc. & Alloy & Spc. & Alloy & Spc. & Alloy & Spc. \\
\hline Total \# spc & 144 & 1028 & 40 & 224 & 55 & 367 & 3 & 45 & 173 & 1664 \\
\hline DCT matrix & 3 & 14 & & & 3 & 54 & 3 & 45 & 3 & 113 \\
\hline 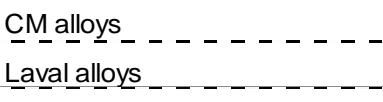 & $-\frac{21}{10}$ & $\begin{array}{l}-\frac{231}{72}- \\
-\underline{72}-\end{array}$ & & & $-\frac{13}{-}-$ & $-\frac{92}{48}-$ & & & $\begin{array}{l}-\frac{21}{-1}- \\
--10\end{array}$ & $\begin{array}{l}-\frac{32}{12}-. \\
-\underline{12} \underline{0}\end{array}$ \\
\hline UCSSB_Commercial alloys _ _ & -13 & 107 & -1 & -4 & -9 & -53 & & & -13 & $-16 \underline{6}$ \\
\hline EPRI alloys & 20 & 141 & & & 6 & 21 & & & 20 & 162 \\
\hline $\begin{array}{l}\text { ORNL alloys }-------- \\
\text { RR alloys }\end{array}$ & $-\frac{5}{57}$ & $-\frac{64}{356}-$ & $-\frac{5}{11}-$ & $\begin{array}{r}41 \\
80 \\
\end{array}$ & $\frac{8}{8}$ & $-\frac{51}{48}$ & & & $--\frac{9}{68}$ & $-\frac{156}{484}$ \\
\hline 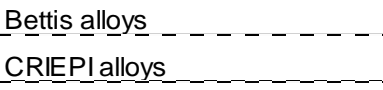 & $-\underline{5}$ & -25 & --- & $\begin{array}{l}--- \\
65\end{array}$ & 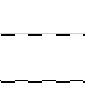 & - & & & $-\frac{5}{13}-$ & $-\frac{25}{65}$ \\
\hline OV model alloys & 9 & 15 & 10 & 34 & & & & & 10 & 49 \\
\hline Diffusion Multiples & 1 & 3 & & & & & & & 1 & 3 \\
\hline
\end{tabular}

More detailed lists of alloys and specimens are shown in Appendix A and Appendix B, with Appendix $\mathrm{B}$ indicating the irradiation temperatures for the various alloys and specimens. Additionally, Appendix $\mathrm{C}$ contains individual tables for the various groups of materials for easier reference by material group. In summary, a variety of relatively small specimens of many different RPV steels are being irradiated in UCSB ATR-2, including many materials that have been irradiated and tested in previous test reactor and surveillance programs at different flux levels. 


\section{Table 3.2. List of archival surveillance materials supplied by Westinghouse and Florida Power and Light for the ATR-2 experiment.}

\begin{tabular}{|c|c|c|c|}
\hline Plant & Material & Heat Number & Specimen Provided \\
\hline Farley Unit 2 & SMAW & BOLA & $\begin{array}{l}\text { One (1) } 1 / 2 \mathrm{~T}-\mathrm{CT} \\
\text { “CW25” }\end{array}$ \\
\hline Farley Unit 2 & SA533B-1 & C7466-1 & $\begin{array}{c}\text { Two (2) 1/2T-CT } \\
\text { “CT29” and “CL28”(a) }\end{array}$ \\
\hline V.C. Summer & Linde 124 Weld & 4P4784 & $\begin{array}{l}\text { One (1) 1/2T-CT } \\
\text { “CW26” }\end{array}$ \\
\hline Kewaunee & Linde 1092 Weld & 1P3571 & $\begin{array}{l}0.5 ” \text { x 3" x 1.5” slice of } \\
\text { weldment (weld marked) }\end{array}$ \\
\hline Maine Yankee & Linde 1092 Weld & 1P3571 & $\begin{array}{c}\text { Two (2) untested tensile } \\
\text { “4KL” and “3J2” } \\
\text { Two (2) broken Charpy } \\
\text { halves from specimen “372” }\end{array}$ \\
\hline Farley Unit 1 & Weld & 33A277 & \\
\hline $\begin{array}{l}\text { Beaver Valley } \\
\text { Unit } 2\end{array}$ & Plate & B9004-1 & Block $5 \times 2.25 \times 2.375$ in. \\
\hline Kewaunee & Forging, SA 508-2 & B6307-1 & Block $3.19 \times 0.875 \times 0.55$ in. \\
\hline $\begin{array}{l}\text { Turkey Point } \\
\text { Unit } 4\end{array}$ & $\begin{array}{l}\text { Linde } 80 \text { Weld, SA- } \\
1094\end{array}$ & $\begin{array}{l}\text { Weld wire heat } \\
\# 71249 \text { and } \\
\text { Linde } 80 \text { flux lot } \\
8457 .\end{array}$ & $\begin{array}{c}\text { Block } 3.375 \times 4.25 \times 8.625 \text { in. } \\
\text { (Block returned following } \\
\text { machining of specimens) }\end{array}$ \\
\hline
\end{tabular}

Notes:

(a) “CT" refers to transverse orientation and "CL" refers to longitudinal orientation.

Regarding test specimens, Figure 3.1 shows the multi-purpose coupon (MPC), also referred to as multi-purpose disc specimen, that will be used to perform microhardness testing and shear punch testing, and will also provide material for subsequent fabrication of specimens for microstructural examination by various techniques such as atom probe tomography (APT), smallangle neutron scattering (SANS), transmission electron microscopy (TEM), etc. Figure 3.2 shows the loading concept for the multi-purpose disc, the square Bettis coupons, and dosimetry canisters into the sub-capsule holders. Figure 3.3 shows the tensile specimen and the sub-capsule loading concept. Tensile specimens will be tested in accordance with ASTM Standard Test Procedure E8 to obtain yield and ultimate strengths for comparison with those of the unirradiated condition and with the microhardness and shear punch results. Those results will be correlated to ascertain the effects of irradiation on hardening. In that regard, Figure 3.4 shows the excellent correlation between tensile specimen yield strength and shear punch strength measurements. The linear fit to those data is $\sigma_{\mathrm{y}}=$ $1.77 \tau_{\mathrm{y}} \pm 16 \mathrm{MPa}$, with the value of 1.77 very close to the von Mises value of 1.73 [7]. Figure 3.5 shows the DCT specimen design and sub-capsule loading concept. The DCT specimens will be tested in accordance with ASTM Standard Test Method E-1921 to obtain the reference temperature, $\mathrm{T}_{0}$, for comparison with that of the unirradiated condition. 

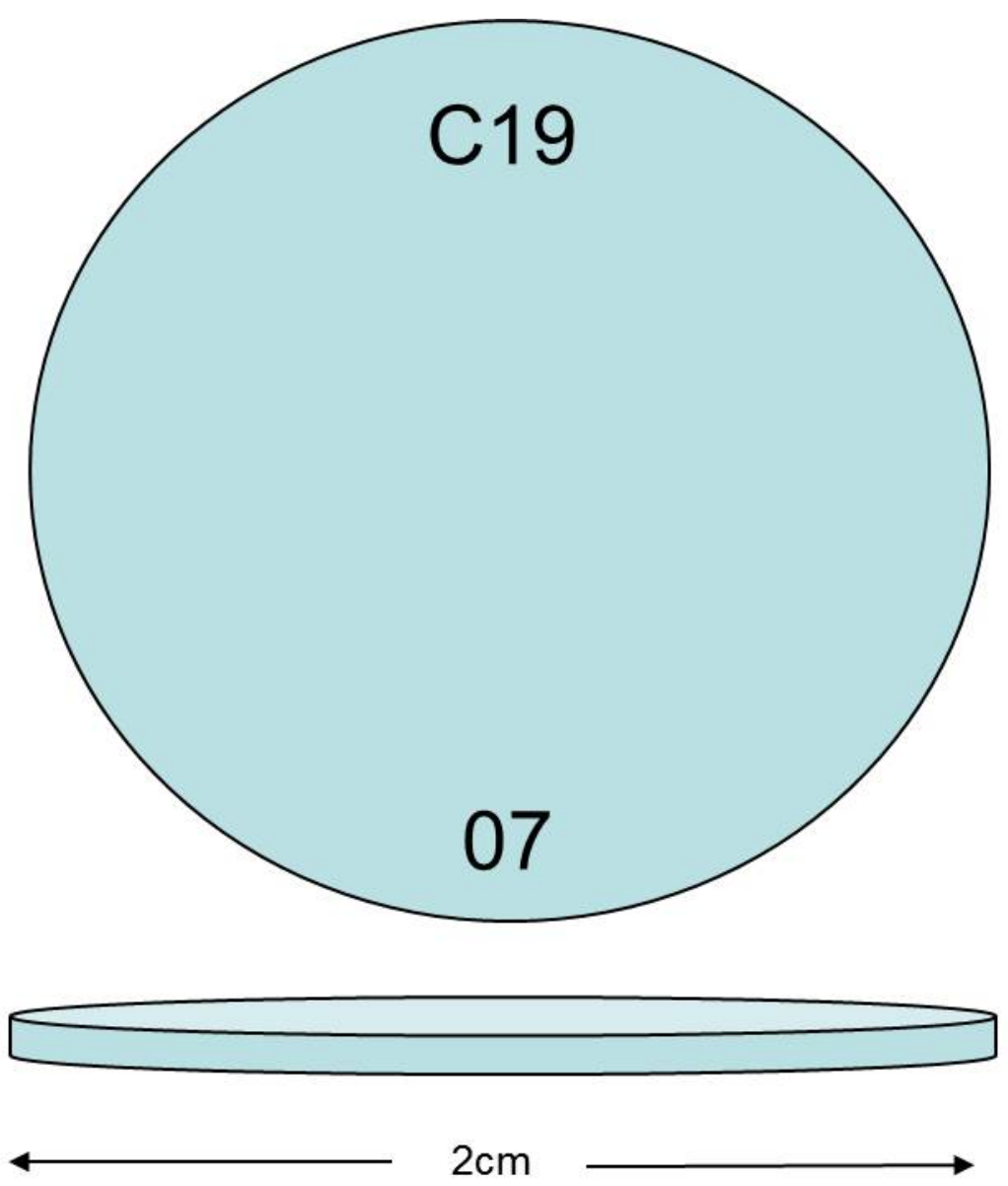

$-0.5 \mathrm{~mm}$

Figure 3.1. Schematic diagram of multi-purpose disc specimen with diameter and thickness indicated.
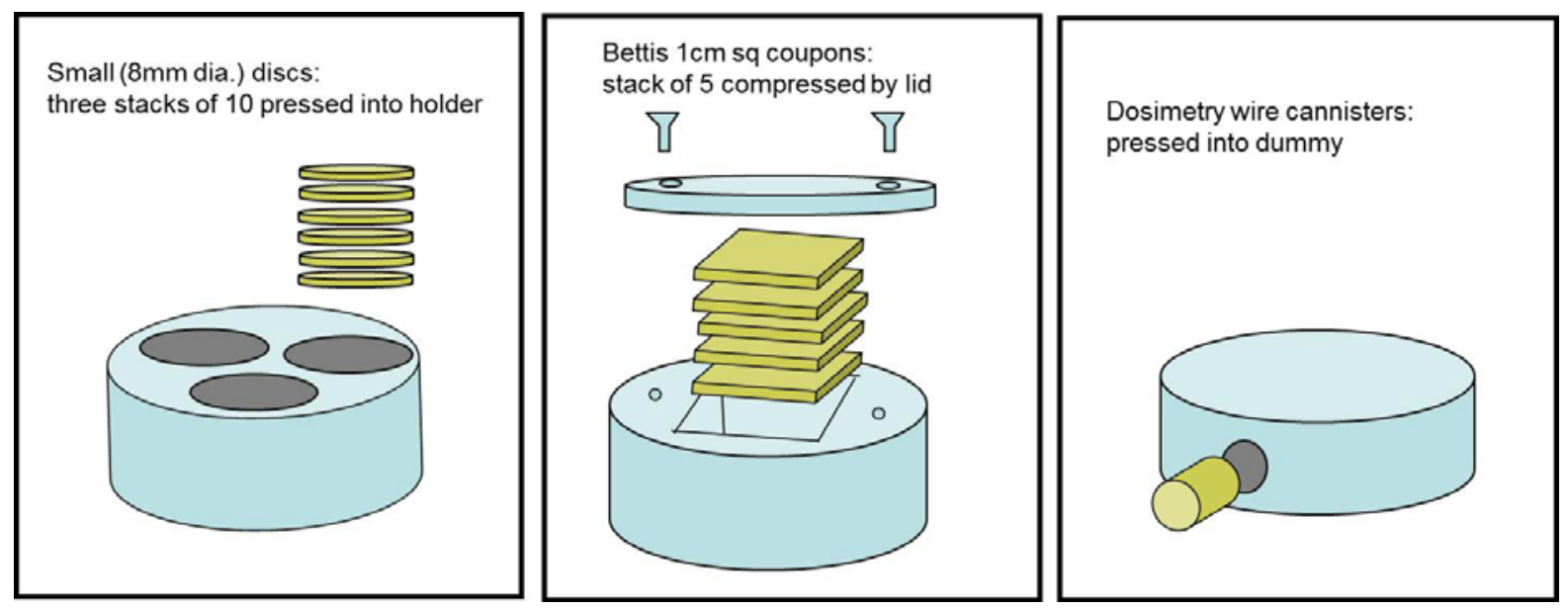

Figure 3.2. Schematic diagram showing concept for loading of multi-purpose disc specimens, Bettis coupons, and dosimetry wire canisters into the sub-capsule holders. 


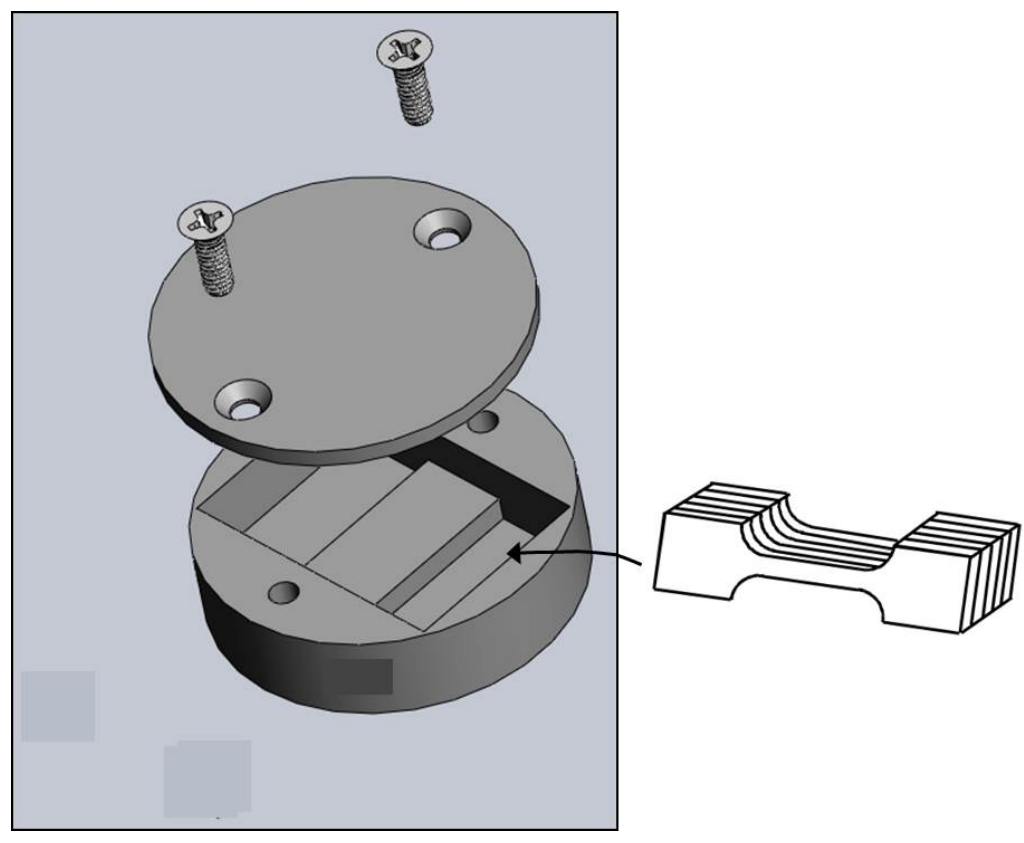

Figure 3.3, Schematic diagram showing concept for loading of tensile specimen into sub-capsule holders.

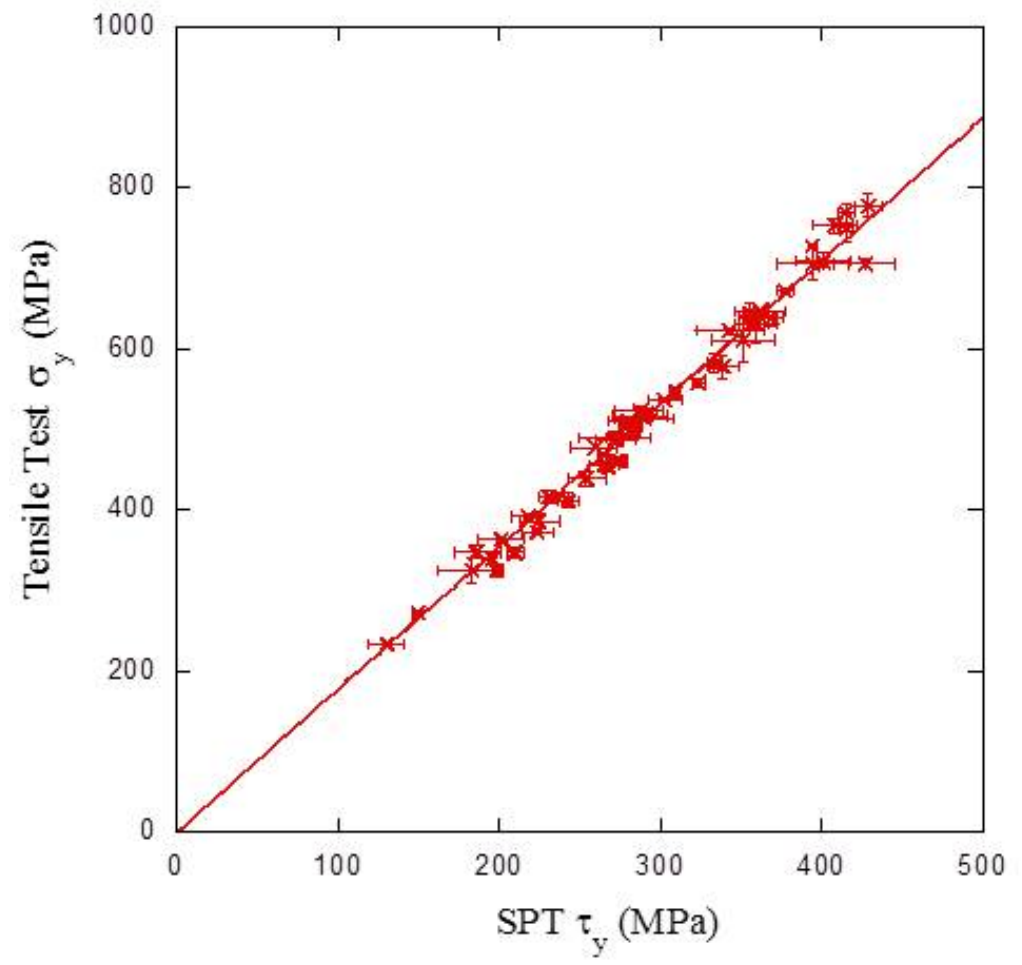

Figure 3.4. Yield strength from tensile specimens vs shear punch tests indicating an excellent correlation. 

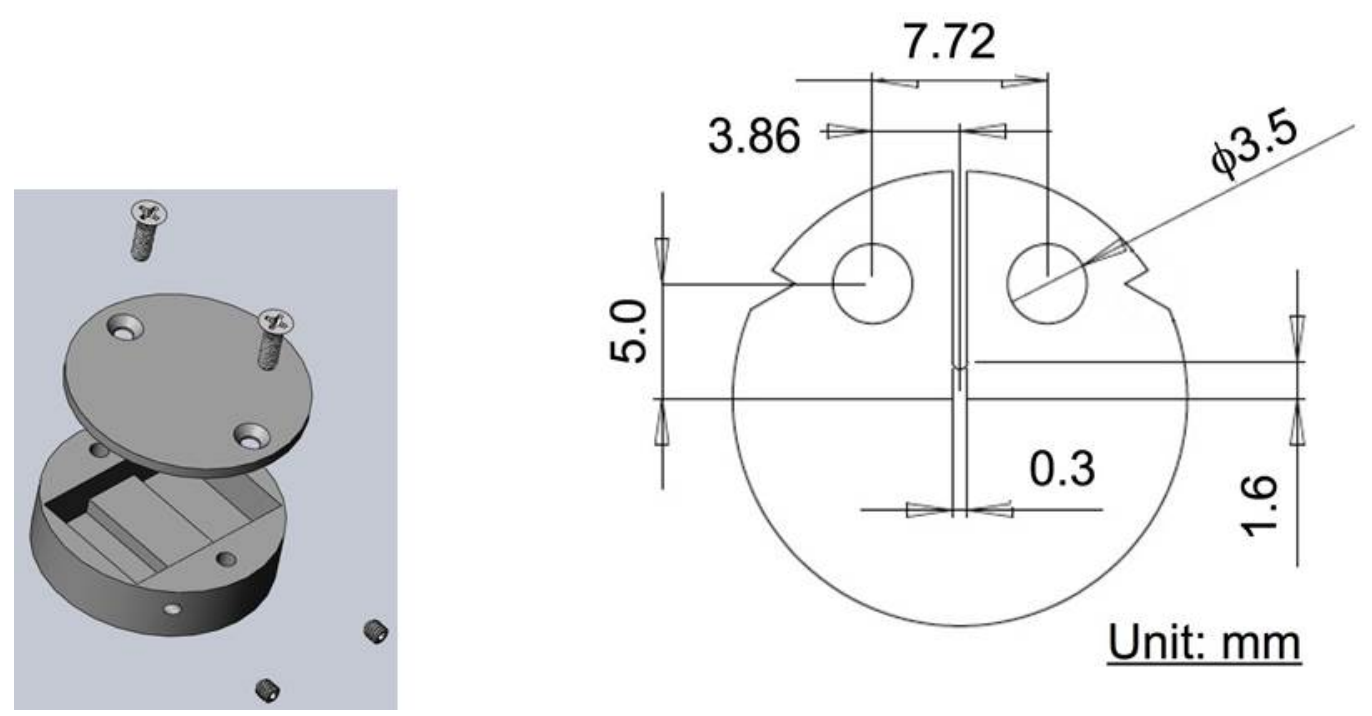

Figure 3.5. Schematic diagram showing disc compact specimen design and holder for loading specimens into sub-capsules.

Figure 3.6 shows a schematic diagram of the device designed by UCSB to perform shear punch testing of the multi-purpose disc specimens.

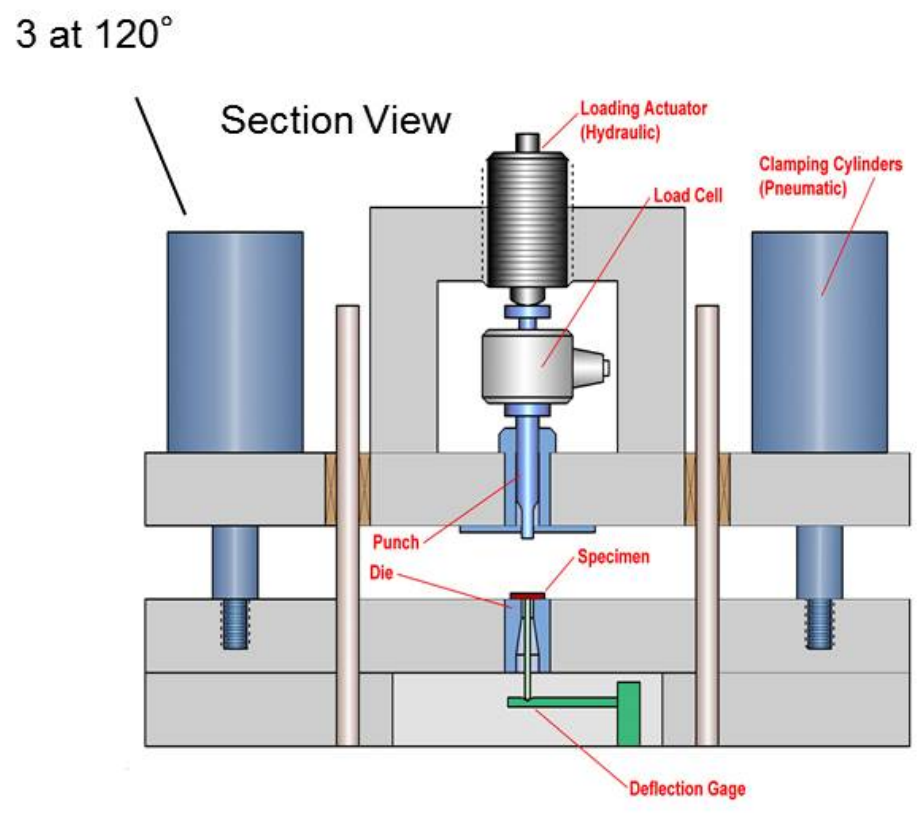

Stand alone SP apparatus

Figure 3.6. Stand-alone conceptual apparatus designed by UCSB for shear punch testing of the multipurpose disc specimens. 
A diffusion-multiple specimen was also designed and prepared by UCSB and is included in the capsule. A schematic drawing of the specimen is shown in Figure 3.7 and consists of two pure elements, copper and nickel, compressed into an opening in a larger disc. Three of these specimens are included in the capsule at positions of $290^{\circ} \mathrm{C}$ (two flux levels) and $310^{\circ} \mathrm{C}$ to allow for evaluations of $\mathrm{Cu}-\mathrm{Ni}$ diffusion variables and phase boundaries. The larger disc is a UCSB Alloy designated OV1, a $\mathrm{Fe} / 1.6 \mathrm{Mn}$ material.

\section{CURRENT STATUS OF THE ATR-2 EXPERIMENT}

Fabrication and assembly of the UCSB ATR-2 irradiation test assembly was completed in late spring of 2011 and was successfully installed in the ATR on May 26, 2011. The irradiation began on June 7, 2011 and was anticipated to achieve its target fluence of $1 \times 10^{20} \mathrm{n} / \mathrm{cm}^{2}(\mathrm{E}>1 \mathrm{MeV})$ in the autumn of 2012. Thermocouple monitors during the course of the irradiation campaign have shown that the specimens are generally being irradiated at or close to their target temperatures, but the final determination of irradiation temperatures and dosimetric information (i.e., neutron flux and fluence) will be performed following removal of the capsule from the reactor.

A number of delays in operation of the ATR have pushed the completion of the ATR-2 irradiation campaign into March of 2014. Chief among these is the Powered Axial Locator Mechanism (PALM) cycle, which is occasionally performed by the ATR for complex transient testing and which can simulate multiple start-up and shutdown cycles of tests for fuels and materials [8]. The PALM tests normally last from a few hours to a couple of days, but some experiments must be removed from the reactor when a PALM test is performed. This is the case for the ATR-2 capsule which was removed in anticipation of the PALM cycle experiment, which occurred in the Spring of 2013.

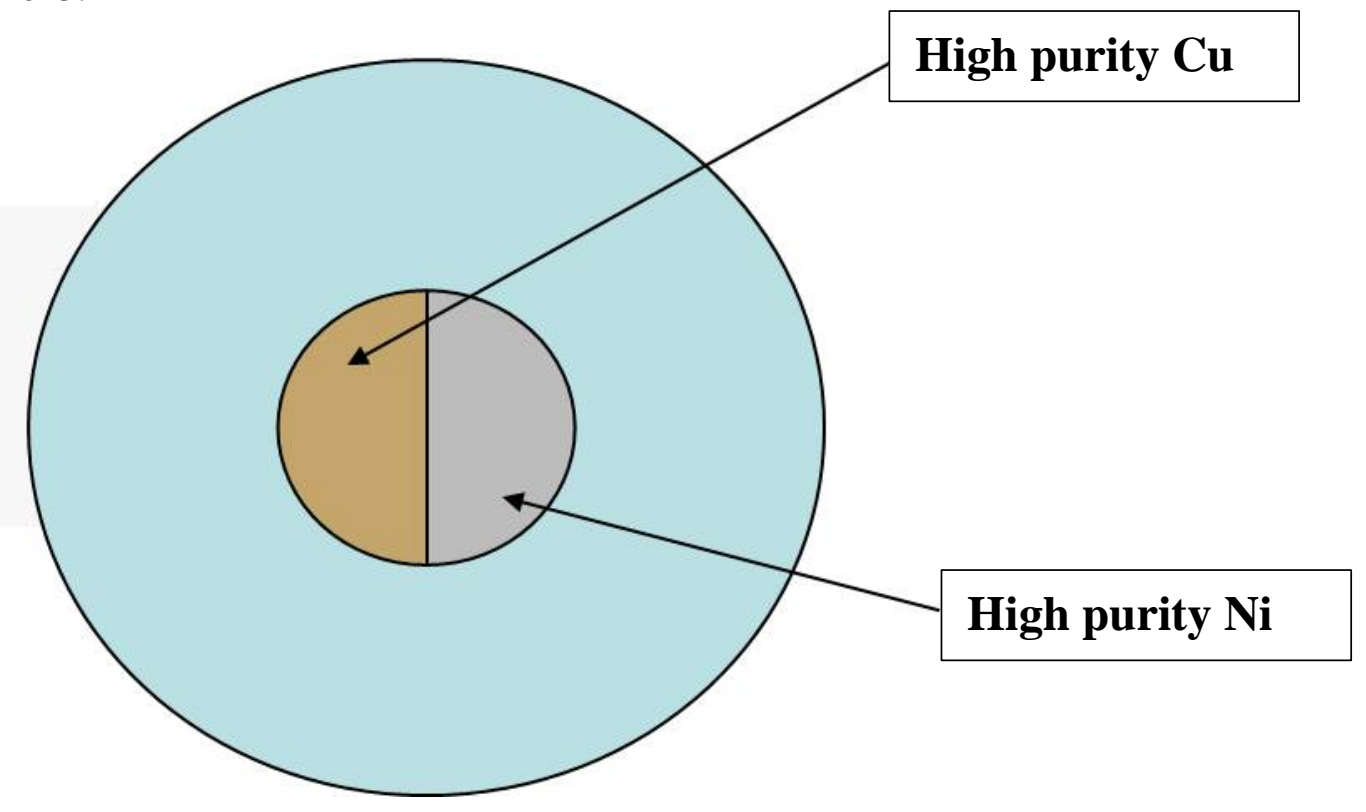

Figure 3.7. Schematic drawing of diffusion-multiple specimen, with high purity $\mathrm{Cu}$ and Ni embedded in a larger disc (UCSB Alloy OV1, an Fe/1.6Mn alloy). 
At the time of the ATR shutdown, the average neutron fluence $(>1 \mathrm{MeV})$ for the ATR-2 capsule was $6.34 \times 10^{19} \mathrm{n} / \mathrm{cm}^{2}$, with a peak fluence of $8.76 \times 10^{19} \mathrm{n} / \mathrm{cm}^{2}$. Thus, a decision was made to have the capsule reinserted following the PALM cycle. This decision compelled design of a mock up experiment to load and remove the capsule. The ATR experiment team designed such an experiment and the necessary tool, and performed a mock up experiment. A mockup of the ATR-2 test train was placed in the ATR tank and was successfully transferred through the drop chute into the canal. A new tool was designed to grip the bottom of the experiment without damaging the thin walled tubing. The mockup test demonstrated that the new tool could maintain the correct orientation of the experiment needed to complete the transfer. Subsequently, the real test train was successfully transferred to the canal using the same process that was practiced with the mockup. The experiment remained in the canal through the PALM cycle, then was transferred back into the ATR for additional cycles. The ATR-2 Experiment Manager reported that the team performing this work did an excellent job in transferring the capsule.

Based on the projected cycle times, the average and peak fluences would be 8.71 and $12.0 \times 10^{19} \mathrm{n} / \mathrm{cm}^{2}$ after two additional cycles (cycles 154A and 154B), while they would be 1.01 and $1.40 \times 10^{19} \mathrm{n} / \mathrm{cm}^{2}$ after three additional cycles, respectively. Because of additional delays in reactor operation, a decision has been made to withdraw the ATR-2 capsule at the end of cycle 154B, currently anticipated for the end of March 2014.

Following completion of the irradiation campaign, the ATR-2 capsule will reside in the ATR canal until ready for shipment to ORNL for disassembly and conduct of the post-irradiation activities. The current plan for conduct of the post-irradiation examination (PIE) activities is described in Section 5.

\section{POST-IRRADIATION EXAMINATION PLAN}

The PIE plan for examination of the ATR-2 experiment is considered to be fluid and flexible to accommodate changing emphasis on results in order to meet project objectives. Specific test sequences will be determined by priority guidelines as well as on final determination of irradiation temperatures and dosimetric data for the wide range of specimens and materials. The PIE activities are substantial due to the very large number of materials and specimens and will involve multiple collaborations with many organizations. Moreover, the availability of facilities and test equipment can easily require changes to the initial schedule in order to maximize productivity. Cost estimates for the PIE are underway, but are highly dependent on the number of tests that would need to be performed in remote hot cells as opposed to the ORNL Low Activated Materials Development and Analysis (LAMDA) laboratory. The general steps for the PIE evaluation are as follows:

1. The ATR-2 capsule will be shipped from INL to ORNL for receipt at the hot cells of Building 3525, the Irradiated Fuels Examination Laboratory (IFEL).

2. The capsule will be opened in the IFEL to retrieve and identify the sub-capsules.

3. Sub-capsules will be shipped to the hot cells of Building 3025E, the Irradiated Materials Examination and Testing (IMET) facility.

4. Sub-capsules will be opend to retrieve and identify individual specimens, with further packaging of like specimens by material/specimen type/irradiation temperature/fluence.

5. Dosimeter packets will be retrieved for individual dosimeter identification and shipment to IFEL for counting and analysis of the fluence for each dosimeter.

6. Activity measurements of individual specimen packets will be performed in preparation for shipment to other locations for testing, such as the LAMDA laboratory in Building 4508. It is notable that the ATR-2 experiment was specifically designed with a gadolinium shield to significantly reduce the thermal neutron flux with the intended consequence of reduced activation of the specimens. This should minimize the need for mechanical testing in remote hot cells, with concomitant reductions in cost and increases in productivity. 
7. Small specimens will be punched from selected mutli-purpose discs and shipped to UCSB. Microhardness measurements will be used to complement mechanical testing at ORNL and to conduct mechanism experiments, including post-irradiation annealing studies based on microhardness testing. The annealing studies will also provide a basis to develop remediation annealing and reirradiation models. The small specimens will also be used for extensive characterization studies, including APT, TEM, SANS, and other microstructural/microanalytical evaluations.

8. However, the majority of mechanical property tests will be performed at ORNL. Ultimately, the plan is to perform shear punch tests on a majority of the alloy/irradiation conditions at ORNL, which will take advantage of the automated shear punch instrument developed by UCSB in collaboration with ORNL.

9. The plan is also to perform redundant room temperature tests on the tensile specimens for all corresponding alloy/irradiation conditions.

10. The compact tension specimens will be tested to establish transition temperature shifts and provide additional insight on fracture toughness Master Curve methodology.

11. Testing of the specimens will be performed in accordance with the standard practices where applicable.

The nominal order of priority regarding testing of the various materials is as follows:

1. In the case of the MPC and tensile specimen testing, a preliminary priority sequence of testing will be on the high fluence $\left(290^{\circ} \mathrm{C}\right)$ irradiation condition as follows:

a. ORNL surveillance materials,

b. UCSB and Rolls-Royce alloys that have been irradiated over a wide range of flux in IVAR and other experiments,

c. The Rolls-Royce matrix of new alloys that explore extended RPV compositional space,

d. Selected EPRI, CRIEPI and Bettis alloys that specifically complement the matrix of tests cited in a through c above,

e. Additional tests on other alloys.

2. For MPC and tensile testing, a selected subset of key alloys will be characterized at the lower fluences and at the lower and higher irradiation temperatures in order to establish the hardening dependencies on these variables. The matrix will include the down-selected alloys from items 1a through 1c. Establishing these dependencies will have an equal priority with the compositional-based assessments in item 1 above.

3. The compact tension specimens for each material will be tested in accordance with ASTM E1921 at a minimum of three temperatures to provide $\Delta \mathrm{T}_{0}$ shifts and information on possible changes in Master Curve shape for highly embrittled materials.

4. Additional mechanical property tests will be conducted on a subset of alloys to complement the mechanistically oriented annealing experiments at UCSB and provide a basis for developing remediation annealing models.

5. Extensive microstructural/microanalytical characterization studies using a variety of complementary techniques will be conducted based on mechanistic insight that identified gaps and as guided by the mechanical property test results.

The following is an example of the sequence of measurements that would be made on a specific high priority alloy for various irradiation conditions. This specific example is developed for the Palisades 
RPV weld:

1. Shear punch, tensile and microhardness measurements to establish the changes in yield strength and post-yield constitutive properties for a matrix of irradiation fluence and temperature conditions;

2. Fracture toughness tests to provide $\Delta \mathrm{T}_{0}$ shifts and information on possible changes in Master Curve shape for highly embrittled materials and to relate the $\Delta \mathrm{T}_{0}$ shifts to changes in yield strength. The fracture analysis on this alloy will include fractography and micromechanical evaluations to inform fracture modeling of Master Curve issues;

3. The as-irradiated conditions will be characterized by APT, TEM, SANS and PAS;

4. The material will be subject to a series of post-irradiation annealing treatments followed by microhardness tests, shear punch tests and microstructural/microanalytical characterizations.

An approximate timeline for the testing and evaluations discussed above is shown in Appendix D. The current estimate for shipment of the ATR-2 capsule is the fourth quarter of FY 2014.

\section{SUMMARY}

The primary objective of the LWRSP RPV task is to develop robust predictions of transition temperature shifts (TTS) at high fluence ( $\phi \mathrm{t})$ to at least $10^{20} \mathrm{n} / \mathrm{cm}^{2}(>1 \mathrm{MeV}$ ) pertinent to plant operation of some pressurized water reactors (PWR) for 80 full power years. The RPV task of the LWRS Program is working with various organizations to obtain archival surveillance materials from commercial nuclear power plants to allow for comparisons of the irradiation-induced microstructural features from reactor surveillance materials with those from similar materials irradiated under high flux conditions in test reactors. Additionally, the task is collaborating and cooperating with the University of California Santa Barbara regarding post-irradiation examination of the materials and specimens in the ATR-2 experiment. The ATR-2 capsule is anticipated to complete irradiation at the end of March 2014 with average and peak neutron fluences of about 0.87 and $1.20 \times 10^{20} \mathrm{n} / \mathrm{cm}^{2}(>1$ $\mathrm{MeV}$ ), respectively. This report has summarized the experiment, a detailed description of the materials and test specimens, and the preliminary plan for testing and examination of the irradiated specimens.

\section{REFERENCES}

1. Eason, E. D., G. R. Odette, R. K. Nanstad and T. Yamamoto, “A physically-based correlation of irradiation-induced transition temperature shifts for RPV steels,” Journal of Nuclear Materials, Volume 433, Issues 1-3, February 2013, Pages 240-254. Also in: Eason, E. D., Odette, G. R., Nanstad, R. K. and Yamamoto, T., “A Physically Based Correlation of Irradiation-Induced Transition Temperature Shifts for RPV Steels,” ORNL/TM-2006/530, Oak Ridge National Laboratory, February 2007.

2. Nanstad, R. K. and Odette, G. R., "Reactor Pressure Vessel Issues for the Light-Water Reactor Sustainability Program,” Proceedings of Env. Deg. Conf., 2009.

3. Odette, G. R. and Nanstad, R. K., "Predictive Reactor Pressure Vessel Steel Irradiation Embrittlement Models: Issues and Opportunities,” J. Metals, 61, 7, July 2009. 
4. M.K. Miller, K.A. Powers, R.K. Nanstad, and P. Efsing, “Atom probe tomography characterizations of high nickel, low copper surveillance RPV welds irradiated to high fluences,” J. Nuc. Mat., 437 (2013) 107-115.

5. Nanstad, R. K. and G. R. Odette, "Reactor Pressure Vessel Task of Light Water Reactor Sustainability Program: Milestone Report on Materials and Machining of Specimens for the ATR-2 Experiment,” ORNL/LTR-2011/413, Oak Ridge National Laboratory, January 2011.

6. Nanstad, R. K., “Reactor Pressure Vessel Task of Light Water Reactor Sustainability Program: Assessment of High Value Surveillance Materials,” ORNL/LTR-2011/172, Oak Ridge National Laboratory, June 2011.

7. Dieter, George E., Jr., Mechanical Metallurgy, McGraw-Hill Book Company, New York, 1961.

8. Glover, S. B., "Irradiation Facilities at the Advanced Test Reactor," Transactions of $11^{\text {th }}$ Int. Topical Meeting on Research Reactor Fuel Management (RRFM) and Meeting of the Int. Group on Reactor Research (IGORR), Lyon, France, European Nuclear Society and IGORR in Co-op with IAEA, March, 2007. 


\title{
INTERNAL DISTRIBUTION
}

\author{
Busby, J.T. \\ busbyjt@ornl.gov \\ Chen, $X$. \\ Field, K. G. \\ chenx@ornl.gov \\ fieldkg@ornl.gov \\ Ice, $\mathbf{G}$. \\ Leonard, K.J. \\ icege@ornl.gov \\ leonardk@ornl.gov \\ Le Pape, Y. M. \\ lepapeym@ornl.gov \\ Littrell, K. C. \\ littrellkc@ornl.gov \\ Miller, M.K. \\ Nanstad, R.K. \\ Naus, D.J. \\ Rosseel, T.M. \\ Snead, L. L. \\ Sokolov, M.A. \\ millermk@ornl.gov \\ nanstadrk@ornl.gov \\ nausdj@ornl.gov \\ rosseeltm@ornl.gov \\ sneadll@ornl.gov \\ Williams Jr, D.L. \\ sokolovm@ornl.gov \\ Williams, G. T. \\ williamsdljr@ornl.gov \\ williamsgt@ornl.gov
}

\section{EXTERNAL DISTRIBUTION}

K. McCarthy, Idaho National Laboratory, P.O. Box 1625, Idaho Falls, ID 83415-3860, (Kathryn.Mccarthy@inl.gov)

G. R. Odette, Department of Mechanical Engineering, University of California, Santa Barbara, CA 93106 (odette@engineering.ucsb.edu)

T. Yamamoto, Department of Mechanical Engineering, University of California, Santa

Barbara, CA 93106 (yamataku@engineering.ucsb.edu)

R. Reister, GTN Bldg, 1000 Independence Ave, S.W. Washington, DC 20585,

(Richard.Reister@nuclear.energy.gov) 
ORNL/TM-2013/598

This page intentionally left blank 
APPENDIX A

UCSB ATR-2 Material Key Summary

\begin{tabular}{|c|c|c|c|c|c|c|c|}
\hline \multirow[t]{4}{*}{ Type } & & & Lg Disc & Sm Disc & Tens & DCT & Total \\
\hline & \multicolumn{2}{|l|}{ Total \# alloy/irrad cond } & 594 & 161 & 110 & 3 & \\
\hline & \multicolumn{2}{|l|}{ Total \# spc } & 1028 & 224 & 367 & 45 & 1664 \\
\hline & \multicolumn{2}{|l|}{ Total \# unique alloy cond } & 144 & 40 & 55 & 3 & 173 \\
\hline \multirow[t]{3}{*}{ DCT } & Pal. B weld & PBW & 3 & & 19 & 14 & 36 \\
\hline & UCSB forging (C17 as tempered) & $\mathbf{X Y}$ & 4 & & 18 & 14 & 36 \\
\hline & UCSB forging (LP as tempered) & $\mathbf{L P}$ & 7 & & 17 & 17 & 41 \\
\hline \multirow[t]{11}{*}{$\mathbf{C M}$} & UCSB forging slo stress rel & C3 & 16 & & 6 & & 22 \\
\hline & UCSB forging slo stress rel & $\mathrm{C4}$ & 12 & & & & 12 \\
\hline & UCSB forging slo stress rel & C5 & 12 & & 6 & & 18 \\
\hline & UCSB forging slo stress rel & C6 & 25 & & 20 & & 45 \\
\hline & UCSB forging slo stress rel & C7 & 12 & & 6 & & 18 \\
\hline & UCSB forging slo stress rel & C8 & 6 & & & & 6 \\
\hline & UCSB forging slo stress rel & C9 & 13 & & 6 & & 19 \\
\hline & UCSB forging slo stress rel & C10 & 12 & & 6 & & 18 \\
\hline & UCSB forging slo stress rel & C11 & 14 & & 6 & & 20 \\
\hline & UCSB forging slo stress rel & C12 & 3 & & & & 3 \\
\hline & UCSB forging slo stress rel & C13 & 12 & & & & 12 \\
\hline
\end{tabular}




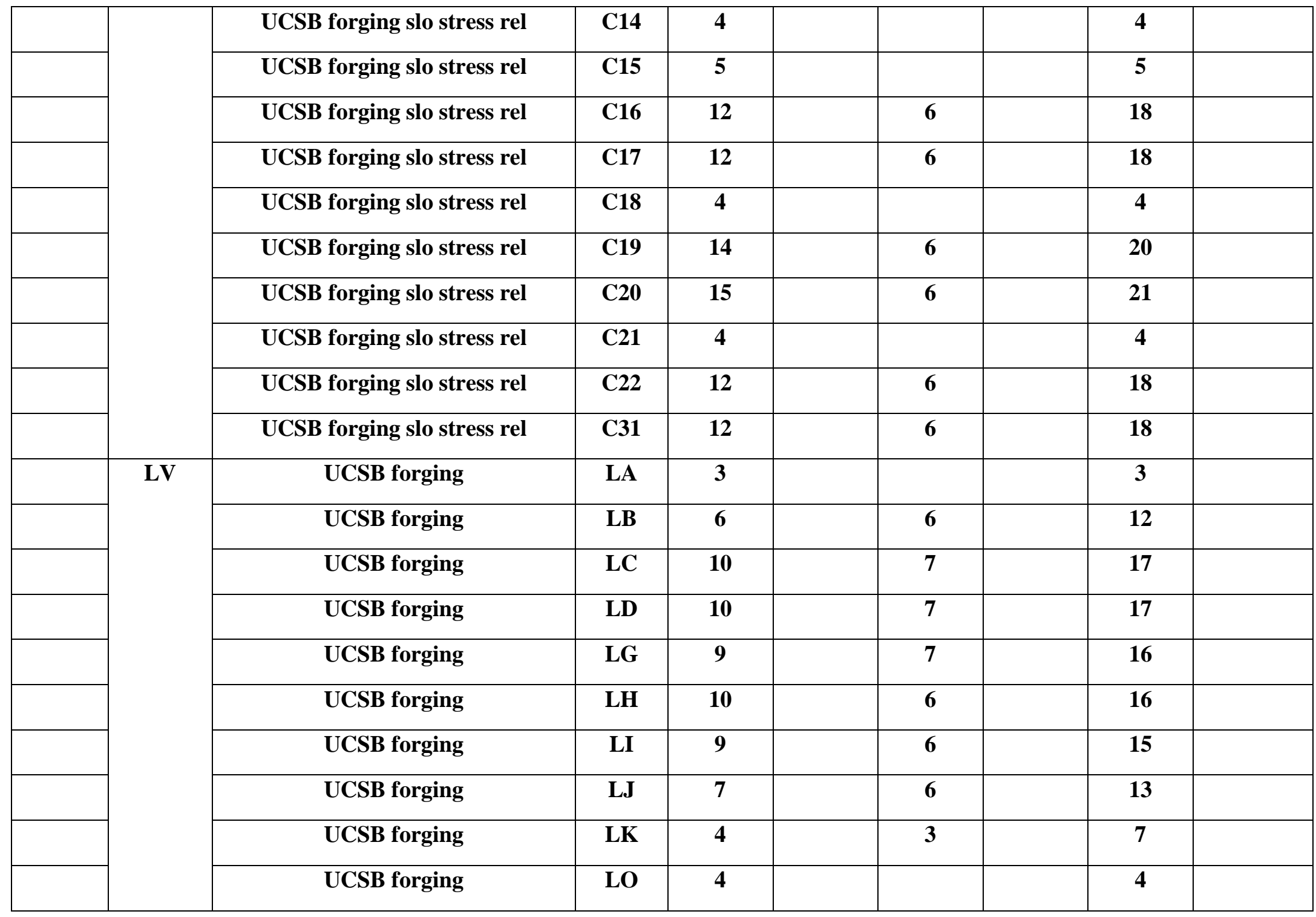




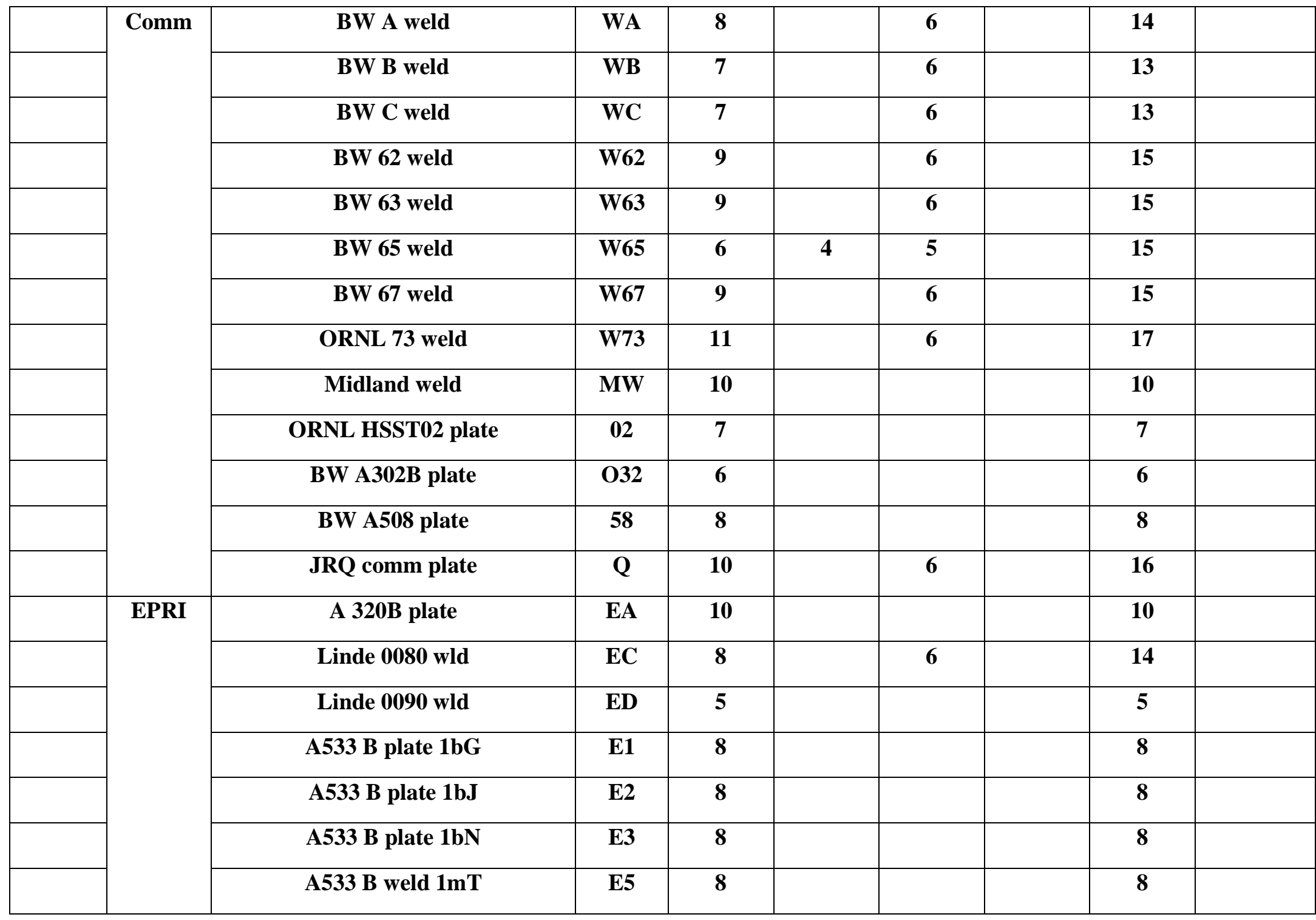




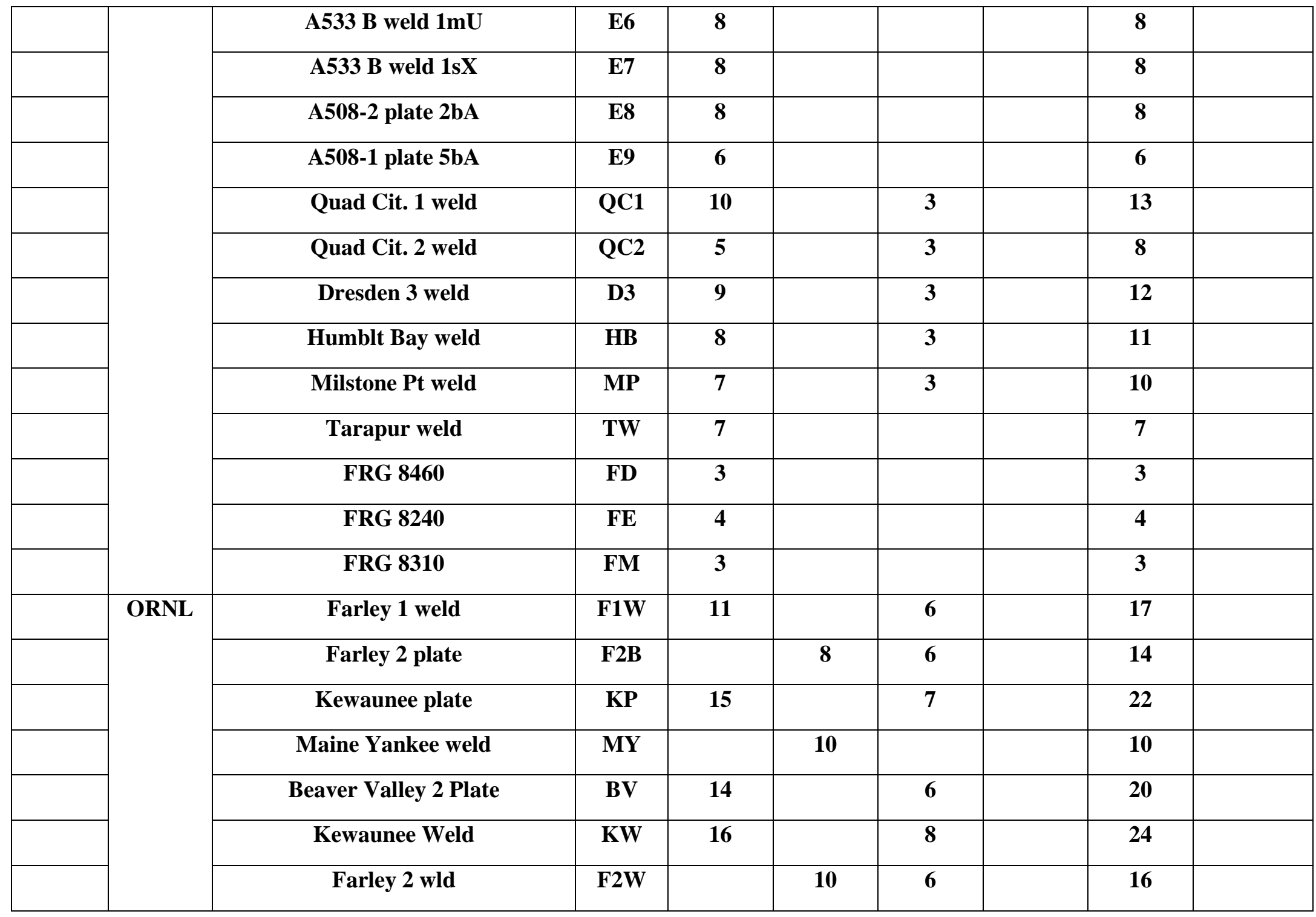




\begin{tabular}{|c|c|c|c|c|c|c|}
\hline & VC SUMMER WELD & VCW & & 10 & 6 & 16 \\
\hline & Turkey Point Weld & TP & 8 & 3 & 6 & 17 \\
\hline \multirow[t]{18}{*}{$\mathbf{R R}$} & Rolls Royce alloy L2385 & R1 & 10 & & 6 & 16 \\
\hline & Rolls Royce alloy L2402 & $\mathbf{R 2}$ & 6 & & & 6 \\
\hline & Rolls Royce alloy L2403 & $\mathbf{R 3}$ & 6 & & & 6 \\
\hline & Rolls Royce alloy L2404 & R4 & 6 & & & 6 \\
\hline & Rolls Royce alloy L2405 & R5 & 6 & & & 6 \\
\hline & Rolls Royce alloy L2406 & R6 & 6 & & & 6 \\
\hline & Rolls Royce alloy L2407 & R7 & 6 & & & 6 \\
\hline & Rolls Royce alloy L2410 & $\mathbf{R 8}$ & 6 & & & 6 \\
\hline & Rolls Royce alloy L2414 & $\mathbf{R 9}$ & 6 & & & 6 \\
\hline & Rolls Royce alloy L2384 & R10 & 9 & & & 9 \\
\hline & Rolls Royce alloy L2408 & R11 & 6 & & & 6 \\
\hline & Rolls Royce alloy L2409 & $\mathbf{R} 12$ & 6 & & & 6 \\
\hline & Rolls Royce alloy L2415 & R13 & 6 & & & 6 \\
\hline & Rolls Royce alloy L2416 & R14 & 6 & & & 6 \\
\hline & Rolls Royce alloy L2417 & R15 & 6 & & & 6 \\
\hline & Rolls Royce alloy L2418 & R16 & 6 & & & 6 \\
\hline & Rolls Royce alloy L2436 & R17 & 6 & & 6 & 12 \\
\hline & Rolls Royce alloy L2435 & R18 & 6 & & & 6 \\
\hline
\end{tabular}




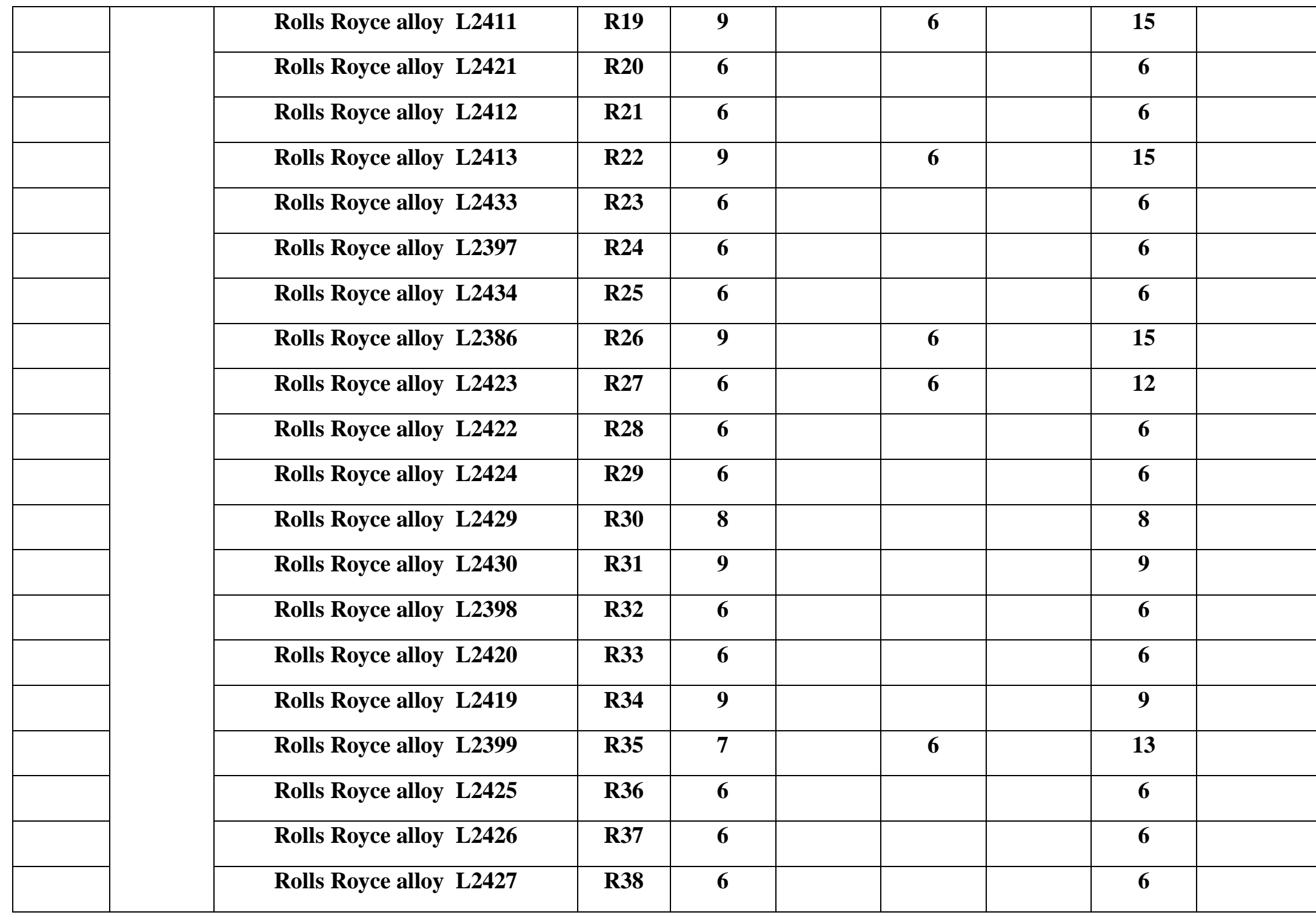




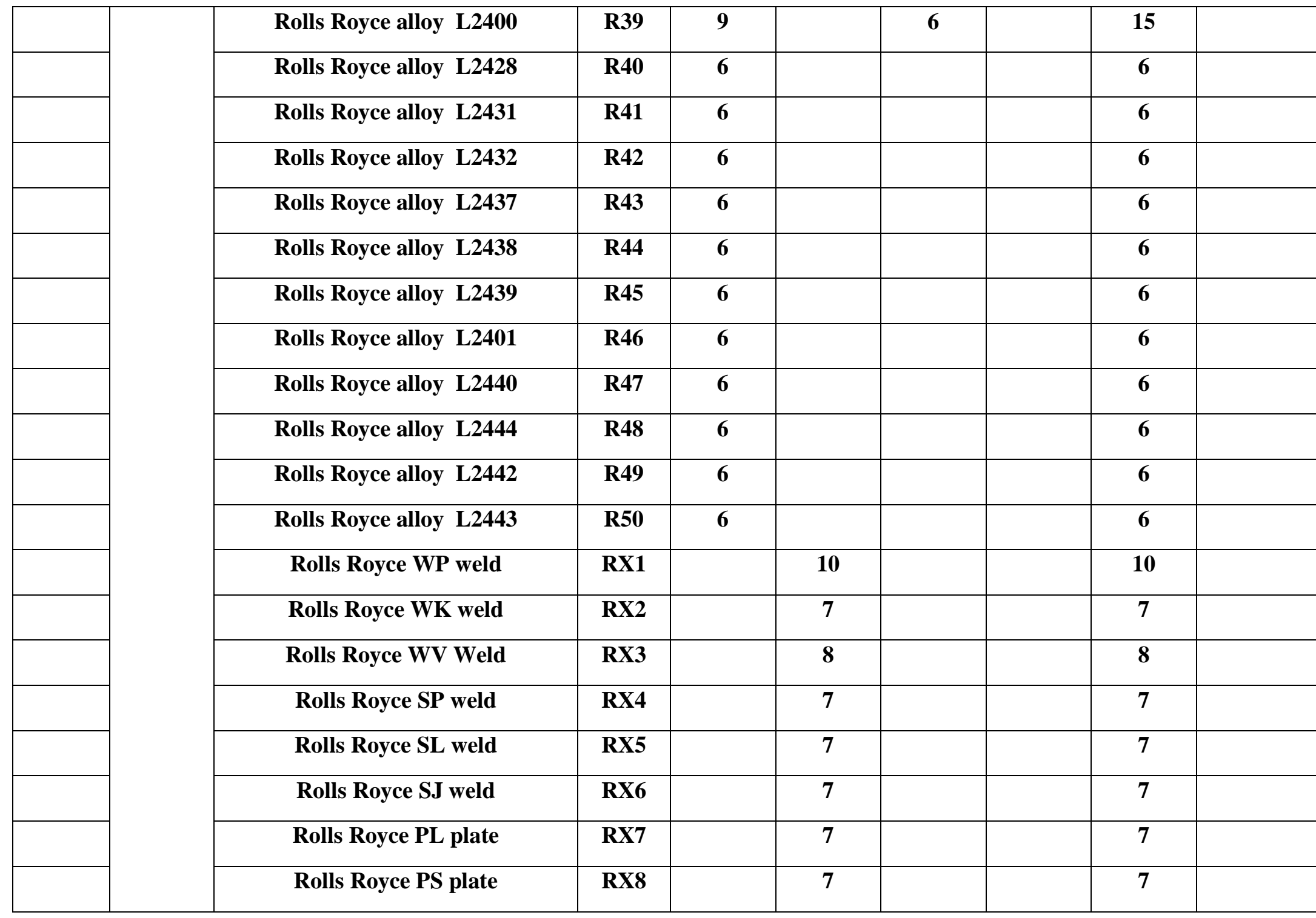




\begin{tabular}{|c|c|c|c|c|c|}
\hline & Rolls Royce FT2 forging & RX9 & & 6 & 6 \\
\hline & Rolls Royce WT weld & RX10 & 4 & & 4 \\
\hline & Rolls Royce FT5 forging & RX11 & & 6 & 6 \\
\hline & Rolls Royce FK forging & RX12 & & 8 & 8 \\
\hline \multirow[t]{6}{*}{ RR HT } & RR40 650 ${ }^{\circ} \mathrm{C} / 5 \mathrm{hr}$ & RH1 & 4 & & 4 \\
\hline & RR40 625 ${ }^{\circ} \mathrm{C} / 5 \mathrm{hr}$ & RH2 & 4 & & 4 \\
\hline & RR22 $600^{\circ} \mathrm{C} / 48 \mathrm{hr}$ & RH3 & 4 & & 4 \\
\hline & RR23 $600^{\circ} \mathrm{C} / 48 \mathrm{hr}$ & RH4 & 4 & & 4 \\
\hline & RR26 600 ${ }^{\circ} \mathrm{C} / 48 \mathrm{hr}$ & RH5 & 4 & & 4 \\
\hline & RR27 $600^{\circ} \mathrm{C} / 48 \mathrm{hr}$ & RH6 & 4 & & 4 \\
\hline \multirow[t]{5}{*}{ Bettis } & Bettis A508 Gr 4N (207N947) & BA & 5 & & 5 \\
\hline & Bettis A508 Gr 4N (124S285) & BB & 5 & & 5 \\
\hline & Bettis Superclean A508 Gr4N (1) & BC & 5 & & 5 \\
\hline & Bettis Superclean A508 GR4N (2) & BD & 5 & & 5 \\
\hline & Bettis 1 Ni- 1.3 Mn Weld & $\mathbf{B E}$ & 5 & & 5 \\
\hline \multirow[t]{5}{*}{ CRIEPI } & EP1 & N1 & & 5 & 5 \\
\hline & EP2 & N2 & & 5 & 5 \\
\hline & EF1 & N3 & & 5 & 5 \\
\hline & EP4 & N4 & & 5 & 5 \\
\hline & EF4 & N5 & & 5 & 5 \\
\hline
\end{tabular}




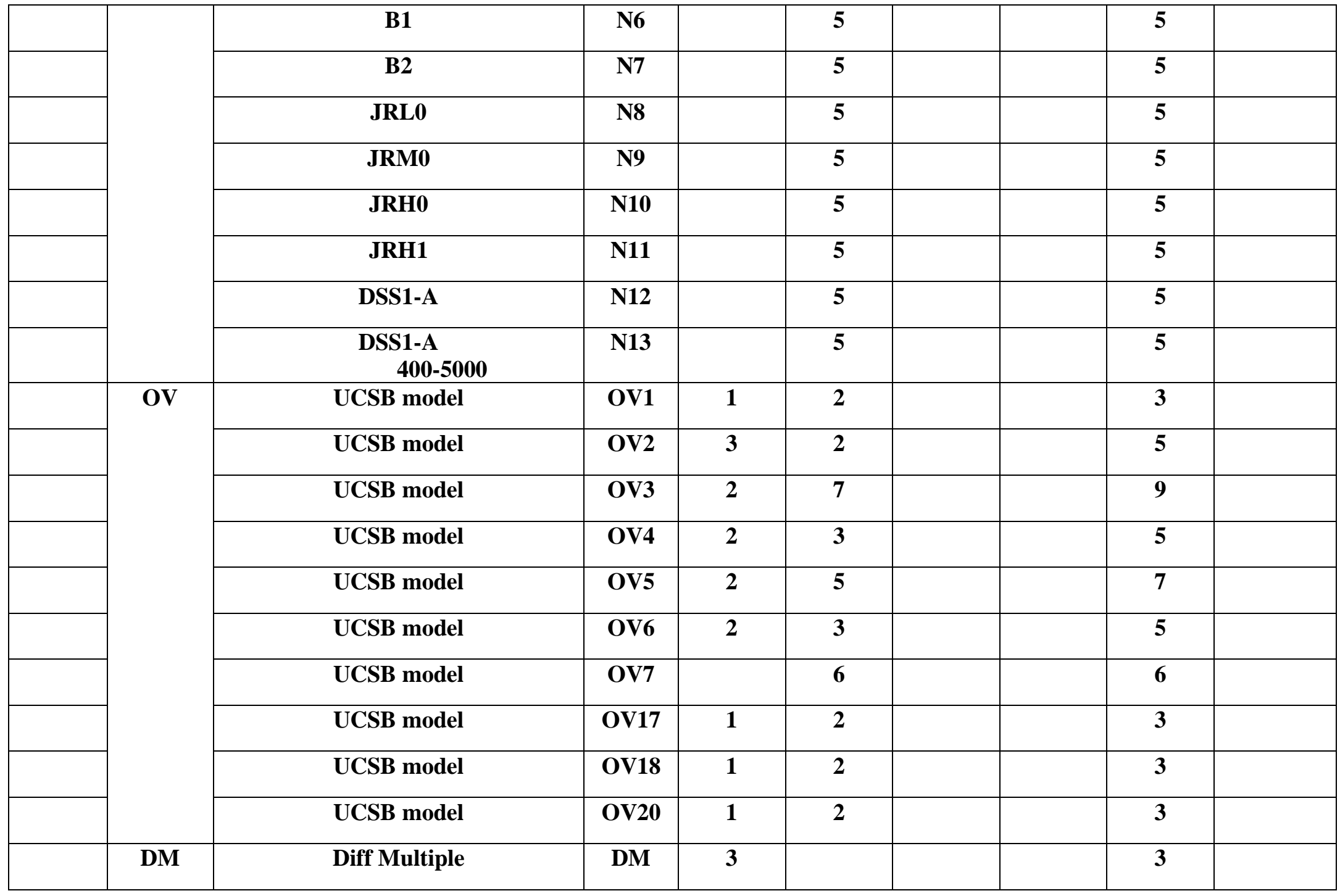


APPENDIX B

UCSB ATR-2 Material Key Details

\begin{tabular}{|c|c|c|c|c|c|c|c|c|c|c|c|c|c|c|c|c|c|c|}
\hline \multirow[t]{2}{*}{ description } & & & $\begin{array}{c}290 \\
\text { hi }\end{array}$ & & & & $\begin{array}{c}290 \\
\text { med }\end{array}$ & & & $\begin{array}{c}290 \\
10\end{array}$ & & & & 250 & & 270 & & 310 \\
\hline & I.D. & $\begin{array}{l}\text { Lg } \\
\text { Disc }\end{array}$ & $\begin{array}{l}\text { Sm } \\
\text { Disc }\end{array}$ & Ten & DC & $\begin{array}{c}\text { Lg } \\
\text { Disc }\end{array}$ & $\begin{array}{c}\text { Sm } \\
\text { Disc }\end{array}$ & ten & $\begin{array}{l}\text { Lg } \\
\text { Disc }\end{array}$ & $\begin{array}{l}\text { Sm } \\
\text { Disc }\end{array}$ & Ten & DCT & $\begin{array}{c}\text { Lg } \\
\text { Disc }\end{array}$ & $\begin{array}{c}\text { Sm } \\
\text { Disc }\end{array}$ & $\begin{array}{c}\text { Lg } \\
\text { Disc }\end{array}$ & $\begin{array}{c}\text { Sm } \\
\text { Disc }\end{array}$ & $\begin{array}{l}\text { Lg } \\
\text { Disc }\end{array}$ & $\begin{array}{c}\text { Sm } \\
\text { Disc }\end{array}$ \\
\hline \#conditions & & 142 & 38 & 53 & 2 & 123 & 29 & 47 & 131 & 32 & 10 & 1 & 72 & 20 & 61 & 21 & 65 & 21 \\
\hline \#specimens & & 252 & 69 & 192 & 28 & 263 & 51 & 141 & 275 & 42 & 34 & 17 & 77 & 20 & 78 & 21 & 83 & 21 \\
\hline \multicolumn{19}{|l|}{ D.C.T. matrix } \\
\hline Pal. B weld & PBW & 3 & & 19 & 14 & & & & & & & & & & & & & \\
\hline $\begin{array}{c}\text { UCSB forging (C17 as } \\
\text { tempered) }\end{array}$ & $\mathbf{X Y}$ & 4 & & 18 & 14 & & & & & & & & & & & & & \\
\hline $\begin{array}{c}\text { UCSB forging (LP as } \\
\text { tempered) }\end{array}$ & $\mathbf{L P}$ & 1 & & & & 2 & & & 4 & & 17 & 17 & & & & & & \\
\hline \multicolumn{19}{|l|}{ CM alloys } \\
\hline $\begin{array}{c}\text { UCSB forging slo stress } \\
\text { rel }\end{array}$ & C3 & 3 & & 3 & & 3 & & 3 & 5 & & & & 1 & & 2 & & 2 & \\
\hline $\begin{array}{c}\text { UCSB forging slo stress } \\
\text { rel }\end{array}$ & C4 & 3 & & & & 3 & & & 2 & & & & & & 2 & & 2 & \\
\hline $\begin{array}{c}\text { UCSB forging slo stress } \\
\text { rel }\end{array}$ & C5 & 3 & & 3 & & 3 & & 3 & 2 & & & & & & 2 & & 2 & \\
\hline $\begin{array}{c}\text { UCSB forging slo stress } \\
\text { rel }\end{array}$ & C6 & 8 & & 9 & & 6 & & 11 & 6 & & & & 1 & & 2 & & 2 & \\
\hline
\end{tabular}




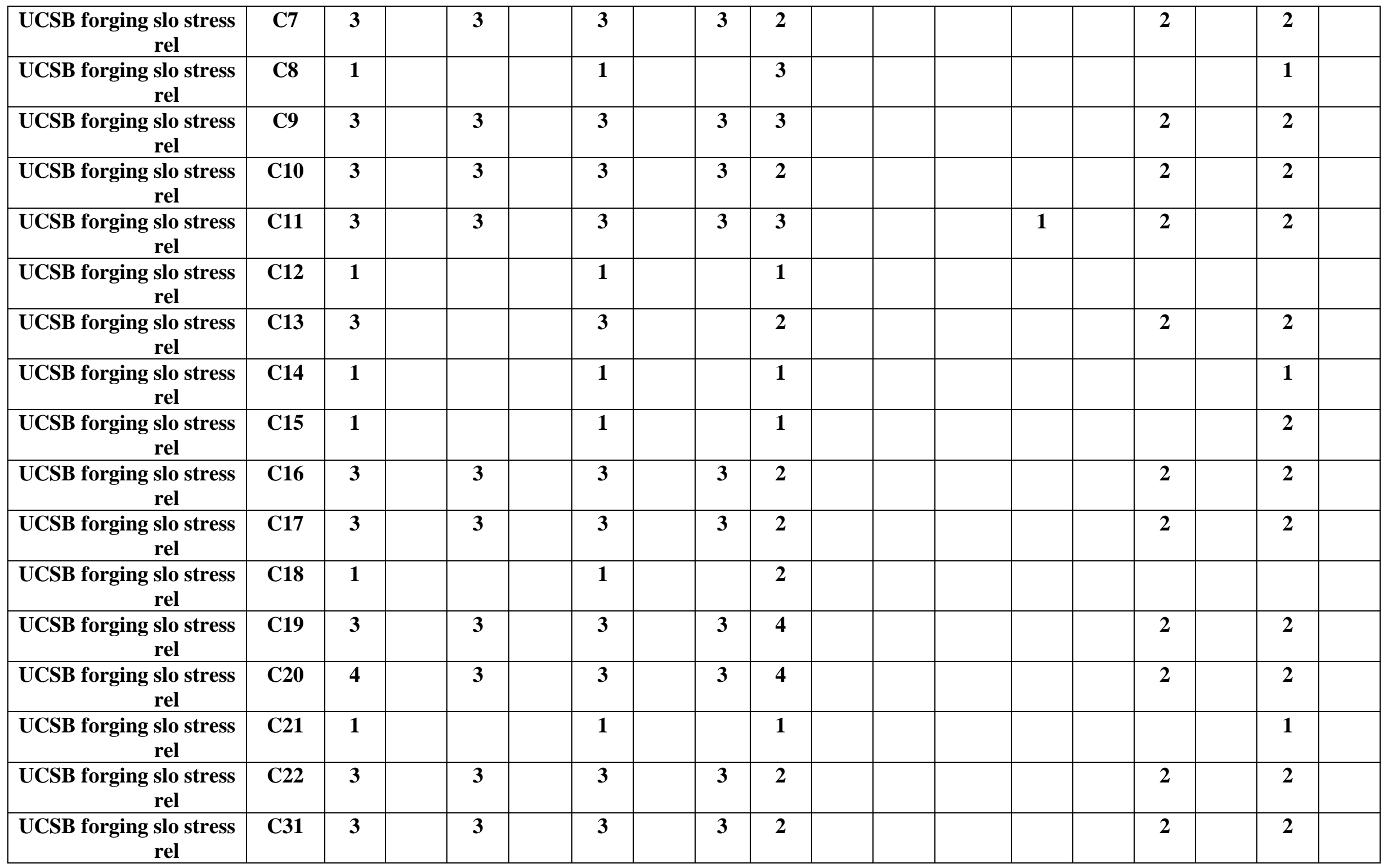




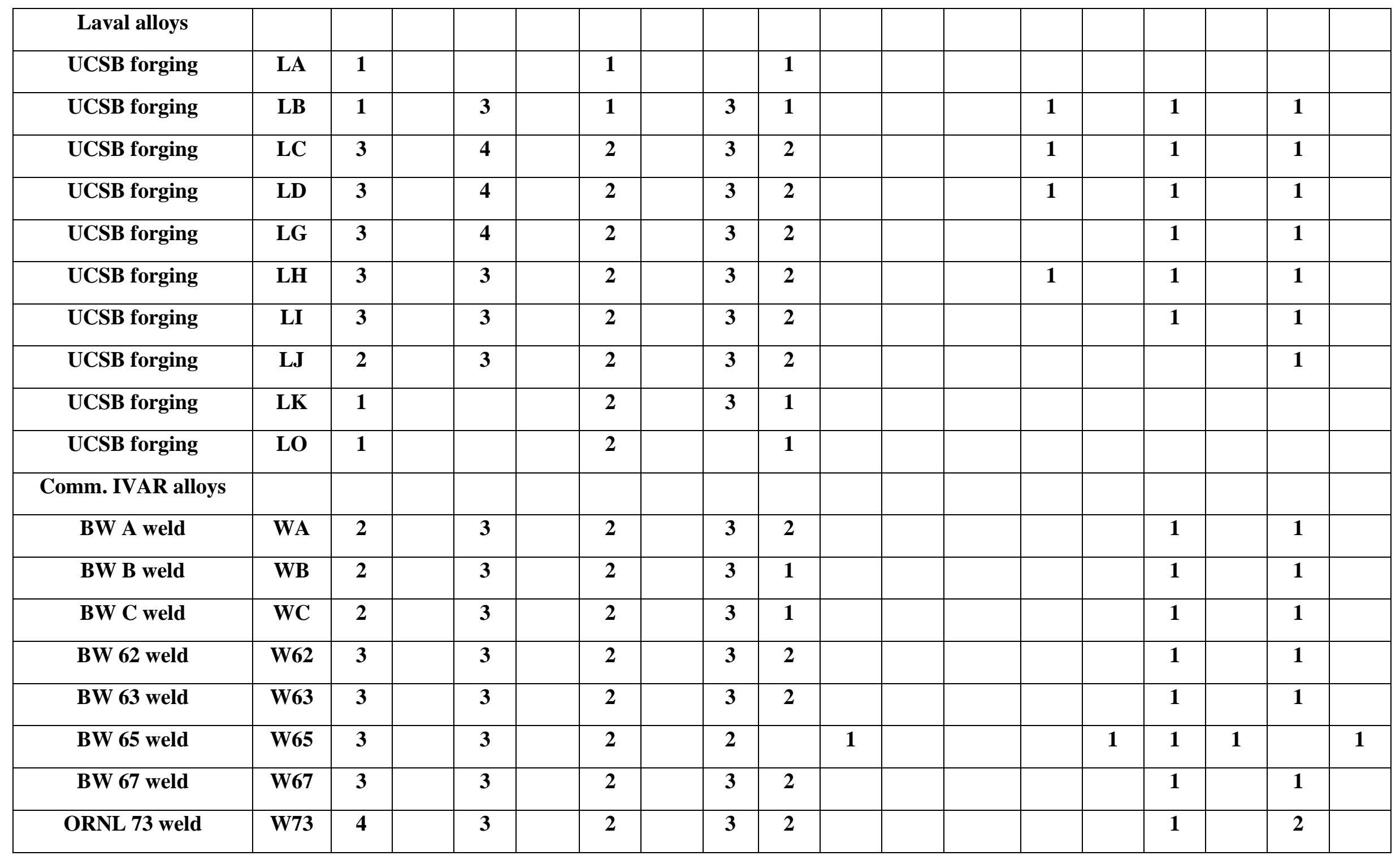




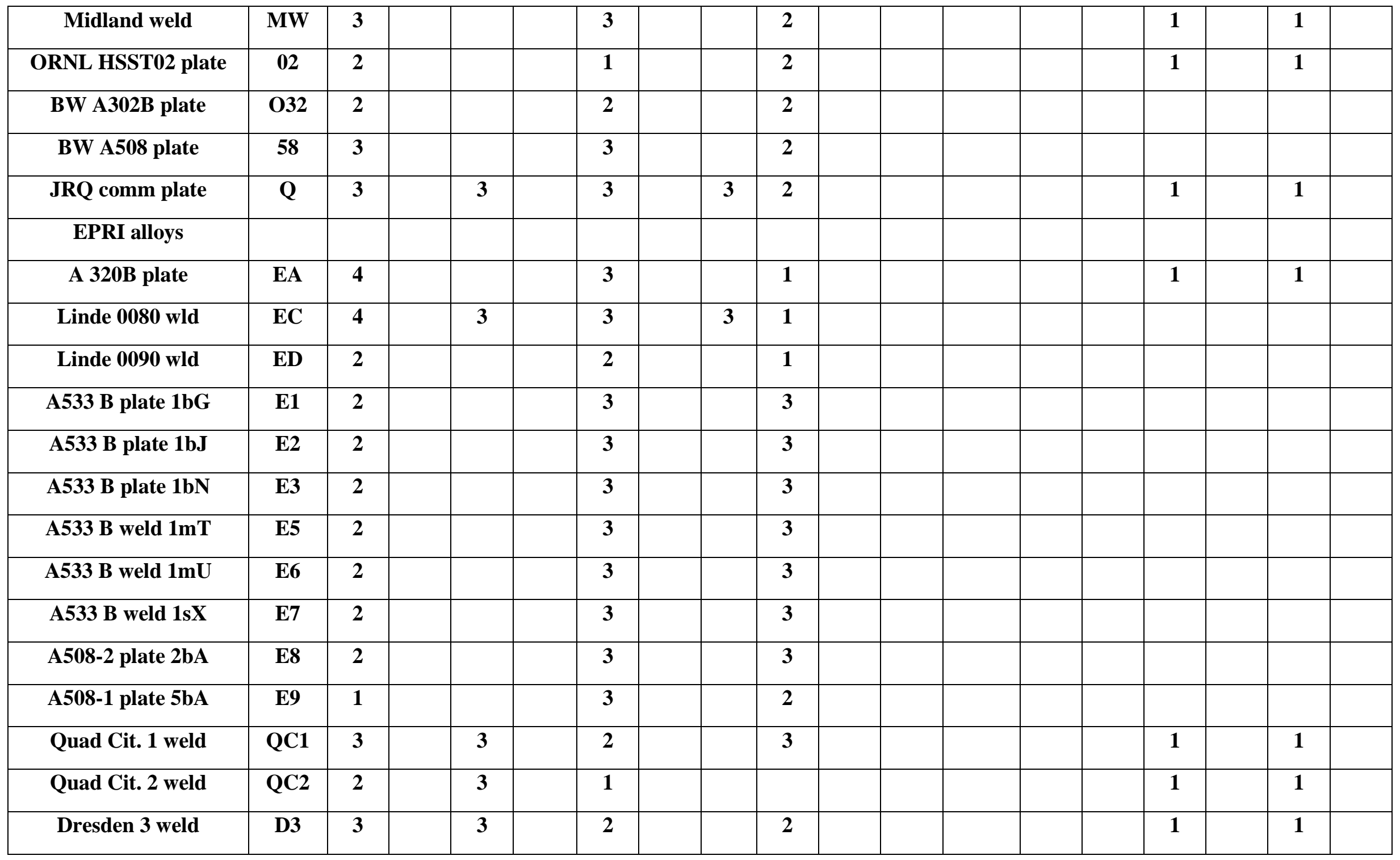




\begin{tabular}{|c|c|c|c|c|c|c|c|c|c|c|c|c|c|c|c|c|}
\hline Humblt Bay weld & HB & 2 & & 3 & 2 & & & 2 & & & & & 1 & & 1 & \\
\hline Milstone Pt weld & MP & 2 & & 3 & 2 & & & 1 & & & & & 1 & & 1 & \\
\hline Tarapur weld & TW & 2 & & & 2 & & & 2 & & & & & 1 & & & \\
\hline FRG 8460 & FD & & & & & & & 1 & & & & & 1 & & 1 & \\
\hline FRG 8240 & FE & 1 & & & & & & 1 & & & & & 1 & & 1 & \\
\hline FRG 8310 & FM & & & & & & & 1 & & & & & 1 & & 1 & \\
\hline \multicolumn{17}{|l|}{ ORNL surv. alloys } \\
\hline Farley 1 weld & F1W & 4 & & 3 & 2 & & 3 & 3 & & & & & 1 & & 1 & \\
\hline Farley 2 plate & F2B & & 2 & 3 & & 2 & 3 & & 1 & & & 1 & & 1 & & 1 \\
\hline Kewaunee plate & KP & 4 & & 3 & 3 & & 4 & 4 & & & 1 & & 2 & & 1 & \\
\hline Maine Yankee weld & MY & & 3 & & & 3 & & & 1 & & & 1 & & 1 & & 1 \\
\hline Beaver Valley 2 Plate & BV & 4 & & 3 & 3 & & 3 & 4 & & & 1 & & 1 & & 1 & \\
\hline Kewaunee Weld & KW & 4 & & 3 & 3 & & 3 & 5 & & 2 & 1 & & 2 & & 1 & \\
\hline Farley 2 wld & F2W & & 3 & 3 & & 3 & 3 & & 1 & & & 1 & & 1 & & 1 \\
\hline VC SUMMER WELD & VCW & & 3 & 3 & & 3 & 3 & & 1 & & & 1 & & 1 & & 1 \\
\hline Turkey Point Weld & $\mathbf{T P}$ & 3 & & 3 & & 3 & 3 & 3 & & & & & 1 & & 1 & \\
\hline \multicolumn{17}{|l|}{ Rolls Royce } \\
\hline $\begin{array}{c}\text { Rolls Royce alloy } \\
\text { L2385 }\end{array}$ & R1 & 1 & & 2 & 2 & & 2 & 3 & & 2 & 1 & & 1 & & 2 & \\
\hline $\begin{array}{c}\text { Rolls Royce alloy } \\
\text { L2402 }\end{array}$ & $\mathbf{R 2}$ & 1 & & & 2 & & & 2 & & & 1 & & & & & \\
\hline $\begin{array}{c}\text { Rolls Royce alloy } \\
\text { L2403 }\end{array}$ & R3 & 1 & & & 2 & & & 2 & & & 1 & & & & & \\
\hline
\end{tabular}




\begin{tabular}{|c|c|c|c|c|c|c|c|c|c|c|}
\hline $\begin{array}{r}\text { Rolls Royce alloy } \\
\text { L2404 }\end{array}$ & R4 & 1 & & 2 & & 2 & & 1 & & \\
\hline $\begin{array}{c}\text { Rolls Royce alloy } \\
\text { L2405 }\end{array}$ & R5 & 1 & & 2 & & 2 & & 1 & & \\
\hline $\begin{array}{c}\text { Rolls Royce alloy } \\
\text { L2406 }\end{array}$ & R6 & 1 & & 2 & & 2 & & 1 & & \\
\hline $\begin{array}{c}\text { Rolls Royce alloy } \\
\text { L2407 }\end{array}$ & R7 & 1 & & 2 & & 2 & & 1 & & \\
\hline $\begin{array}{c}\text { Rolls Royce alloy } \\
\text { L2410 }\end{array}$ & R8 & 1 & & 2 & & 2 & & 1 & & \\
\hline $\begin{array}{r}\text { Rolls Royce alloy } \\
\text { L2414 }\end{array}$ & R9 & 1 & & 2 & & 2 & & 1 & & \\
\hline $\begin{array}{c}\text { Rolls Royce alloy } \\
\text { L2384 }\end{array}$ & R10 & 1 & & 2 & & 3 & & 1 & 1 & 1 \\
\hline $\begin{array}{c}\text { Rolls Royce alloy } \\
\text { L2408 }\end{array}$ & R11 & 1 & & 2 & & 2 & & 1 & & \\
\hline $\begin{array}{r}\text { Rolls Royce alloy } \\
\text { L2409 }\end{array}$ & R12 & 1 & & 2 & & 2 & & 1 & & \\
\hline $\begin{array}{c}\text { Rolls Royce alloy } \\
\text { L2415 } \\
\end{array}$ & R13 & 1 & & 2 & & 2 & & 1 & & \\
\hline $\begin{array}{c}\text { Rolls Royce alloy } \\
\text { L2416 } \\
\end{array}$ & R14 & 1 & & 2 & & 2 & & 1 & & \\
\hline $\begin{array}{c}\text { Rolls Royce alloy } \\
\text { L2417 }\end{array}$ & R15 & 1 & & 2 & & 2 & & 1 & & \\
\hline $\begin{array}{c}\text { Rolls Royce alloy } \\
\text { L2418 } \\
\end{array}$ & R16 & 1 & & 2 & & 2 & & 1 & & \\
\hline $\begin{array}{c}\text { Rolls Royce alloy } \\
\text { L2436 }\end{array}$ & R17 & 1 & 2 & 2 & 2 & 2 & 2 & 1 & & \\
\hline $\begin{array}{c}\text { Rolls Royce alloy } \\
\text { L2435 }\end{array}$ & R18 & 1 & & 2 & & 2 & & 1 & & \\
\hline $\begin{array}{r}\text { Rolls Royce alloy } \\
\text { L2411 } \\
\end{array}$ & R19 & 1 & 2 & 2 & 2 & 3 & 2 & 1 & 1 & 1 \\
\hline $\begin{array}{r}\text { Rolls Royce alloy } \\
\text { L2421 }\end{array}$ & R20 & 1 & & 2 & & 2 & & 1 & & \\
\hline
\end{tabular}




\begin{tabular}{|c|c|c|c|c|c|c|c|c|c|c|}
\hline $\begin{array}{c}\text { Rolls Royce alloy } \\
\text { L2412 }\end{array}$ & R21 & 1 & & 2 & & 2 & & 1 & & \\
\hline $\begin{array}{c}\text { Rolls Royce alloy } \\
\text { L2413 }\end{array}$ & R22 & 1 & 3 & 2 & 2 & 3 & 1 & 1 & 1 & 1 \\
\hline $\begin{array}{c}\text { Rolls Royce alloy } \\
\text { L2433 }\end{array}$ & R23 & 1 & & 2 & & 2 & & 1 & & \\
\hline $\begin{array}{c}\text { Rolls Royce alloy } \\
\text { L2397 }\end{array}$ & R24 & 1 & & 2 & & 2 & & 1 & & \\
\hline $\begin{array}{r}\text { Rolls Royce alloy } \\
\text { L2434 }\end{array}$ & R25 & 1 & & 2 & & 2 & & 1 & & \\
\hline $\begin{array}{c}\text { Rolls Royce alloy } \\
\text { L2386 }\end{array}$ & R26 & 1 & 2 & 2 & 2 & 3 & 2 & 1 & 1 & 1 \\
\hline $\begin{array}{c}\text { Rolls Royce alloy } \\
\text { L2423 }\end{array}$ & R27 & 1 & 2 & 2 & 2 & 2 & 2 & 1 & & \\
\hline $\begin{array}{c}\text { Rolls Royce alloy } \\
\text { L2422 }\end{array}$ & R28 & 1 & & 2 & & 2 & & 1 & & \\
\hline $\begin{array}{c}\text { Rolls Royce alloy } \\
\text { L2424 }\end{array}$ & R29 & 1 & & 2 & & 2 & & 1 & & \\
\hline $\begin{array}{c}\text { Rolls Royce alloy } \\
\text { L2429 } \\
\end{array}$ & R30 & 1 & & 2 & & 2 & & 1 & 1 & 1 \\
\hline $\begin{array}{r}\text { Rolls Royce alloy } \\
\text { L2430 }\end{array}$ & R31 & 1 & & 2 & & 3 & & 1 & 1 & 1 \\
\hline $\begin{array}{c}\text { Rolls Royce alloy } \\
\text { L2398 }\end{array}$ & R32 & 1 & & 2 & & 2 & & 1 & & \\
\hline $\begin{array}{r}\text { Rolls Royce alloy } \\
\text { L2420 }\end{array}$ & R33 & 1 & & 2 & & 2 & & 1 & & \\
\hline $\begin{array}{r}\text { Rolls Royce alloy } \\
\text { L2419 }\end{array}$ & R34 & 1 & & 2 & & 3 & & 1 & 1 & 1 \\
\hline $\begin{array}{c}\text { Rolls Royce alloy } \\
\text { L2399 }\end{array}$ & R35 & 1 & 2 & 2 & 2 & 3 & 2 & 1 & & \\
\hline $\begin{array}{c}\text { Rolls Royce alloy } \\
\text { L2425 } \\
\end{array}$ & R36 & 1 & & 2 & & 2 & & 1 & & \\
\hline $\begin{array}{c}\text { Rolls Royce alloy } \\
\text { L2426 }\end{array}$ & R37 & 1 & & 2 & & 2 & & 1 & & \\
\hline
\end{tabular}




\begin{tabular}{|c|c|c|c|c|c|c|c|c|c|c|c|c|c|c|}
\hline $\begin{array}{c}\text { Rolls Royce alloy } \\
\text { L2427 }\end{array}$ & R38 & 1 & & & 2 & & & 2 & & & 1 & & & \\
\hline $\begin{array}{c}\text { Rolls Royce alloy } \\
\text { L2400 }\end{array}$ & R39 & 1 & & 2 & 2 & & 2 & 3 & & 2 & 1 & & 1 & 1 \\
\hline $\begin{array}{c}\text { Rolls Royce alloy } \\
\text { L2428 }\end{array}$ & R40 & 1 & & & 2 & & & 2 & & & 1 & & & \\
\hline $\begin{array}{r}\text { Rolls Royce alloy } \\
\text { L2431 }\end{array}$ & R41 & 1 & & & 2 & & & 2 & & & 1 & & & \\
\hline $\begin{array}{c}\text { Rolls Royce alloy } \\
\text { L2432 }\end{array}$ & R42 & 1 & & & 2 & & & 2 & & & 1 & & & \\
\hline $\begin{array}{c}\text { Rolls Royce alloy } \\
\text { L2437 }\end{array}$ & R43 & 1 & & & 2 & & & 2 & & & 1 & & & \\
\hline $\begin{array}{c}\text { Rolls Royce alloy } \\
\text { L2438 }\end{array}$ & R44 & 1 & & & 2 & & & 2 & & & 1 & & & \\
\hline $\begin{array}{c}\text { Rolls Royce alloy } \\
\text { L2439 }\end{array}$ & R45 & 1 & & & 2 & & & 2 & & & 1 & & & \\
\hline $\begin{array}{c}\text { Rolls Royce alloy } \\
\text { L2401 }\end{array}$ & R46 & 1 & & & 2 & & & 2 & & & 1 & & & \\
\hline $\begin{array}{r}\text { Rolls Royce alloy } \\
\text { L2440 }\end{array}$ & R47 & 1 & & & 2 & & & 2 & & & 1 & & & \\
\hline $\begin{array}{c}\text { Rolls Royce alloy } \\
\text { L2444 }\end{array}$ & R48 & 1 & & & 2 & & & 2 & & & 1 & & & \\
\hline $\begin{array}{c}\text { Rolls Royce alloy } \\
\text { L2442 }\end{array}$ & R49 & 1 & & & 2 & & & 2 & & & 1 & & & \\
\hline $\begin{array}{c}\text { Rolls Royce alloy } \\
\text { L2443 }\end{array}$ & R50 & 1 & & & 2 & & & 2 & & & 1 & & & \\
\hline Rolls Royce WP weld & RX1 & & 4 & & & 4 & & & 1 & & & 1 & & \\
\hline Rolls Royce WK weld & RX2 & & 2 & & & 2 & & & 2 & & & 1 & & \\
\hline Rolls Royce WV Weld & RX3 & & 2 & & & 2 & & & 3 & & & 1 & & \\
\hline Rolls Royce SP weld & RX4 & & 2 & & & 2 & & & 2 & & & 1 & & \\
\hline Rolls Royce SL weld & RX5 & & 2 & & & 2 & & & 2 & & & 1 & & \\
\hline
\end{tabular}




\begin{tabular}{|c|c|c|c|c|c|c|c|c|c|c|c|c|}
\hline Rolls Royce SJ weld & RX6 & & 2 & & 2 & & 2 & & 1 & & & \\
\hline Rolls Royce PL plate & RX7 & & 2 & & 2 & & 2 & & 1 & & & \\
\hline Rolls Royce PS plate & RX8 & & 2 & & 2 & & 2 & & 1 & & & \\
\hline $\begin{array}{r}\text { Rolls Royce FT2 } \\
\text { forging }\end{array}$ & RX9 & & 2 & & 2 & & 1 & & 1 & & & \\
\hline Rolls Royce WT weld & RX10 & 1 & & 1 & & 1 & & 1 & & & & \\
\hline $\begin{array}{r}\text { Rolls Royce FT5 } \\
\text { forging }\end{array}$ & RX11 & & 2 & & 2 & & 1 & & 1 & & & \\
\hline Rolls Royce FK forging & RX12 & & 2 & & 2 & & 3 & & 1 & & & \\
\hline \multicolumn{13}{|l|}{ RR Heat trt } \\
\hline RR40 $650^{\circ} \mathrm{C} / 5 \mathrm{hr}$ & RH1 & 1 & & 1 & & 1 & & 1 & & & & \\
\hline RR40 625 ${ }^{\circ} \mathrm{C} / 5 \mathrm{hr}$ & RH2 & 1 & & 1 & & 1 & & 1 & & & & \\
\hline RR22 $600^{\circ} \mathrm{C} / 48 \mathrm{hr}$ & RH3 & 1 & & 1 & & 1 & & 1 & & & & \\
\hline RR23 600 ${ }^{\circ} \mathrm{C} / 48 \mathrm{hr}$ & RH4 & 1 & & 1 & & 1 & & 1 & & & & \\
\hline RR26 600 ${ }^{\circ} \mathrm{C} / 48 \mathrm{hr}$ & RH5 & 1 & & 1 & & 1 & & 1 & & & & \\
\hline RR27 600 ${ }^{\circ} \mathrm{C} / 48 \mathrm{hr}$ & RH6 & 1 & & 1 & & 1 & & 1 & & & & \\
\hline \multicolumn{13}{|l|}{ Bettis } \\
\hline $\begin{array}{r}\text { Bettis A508 Gr 4N } \\
(207 N 947)\end{array}$ & BA & 1 & & & & & & 2 & & 1 & 1 & \\
\hline $\begin{array}{r}\text { Bettis A508 Gr 4N } \\
(124 S 285)\end{array}$ & BB & 1 & & & & & & 2 & & 1 & 1 & \\
\hline $\begin{array}{c}\text { Bettis Superclean A508 } \\
\text { Gr4N (1) }\end{array}$ & BC & 1 & & & & & & 2 & & 1 & 1 & \\
\hline $\begin{array}{c}\text { Bettis Superclean A508 } \\
\text { GR4N (2) }\end{array}$ & BD & 1 & & & & & & 2 & & 1 & 1 & \\
\hline
\end{tabular}




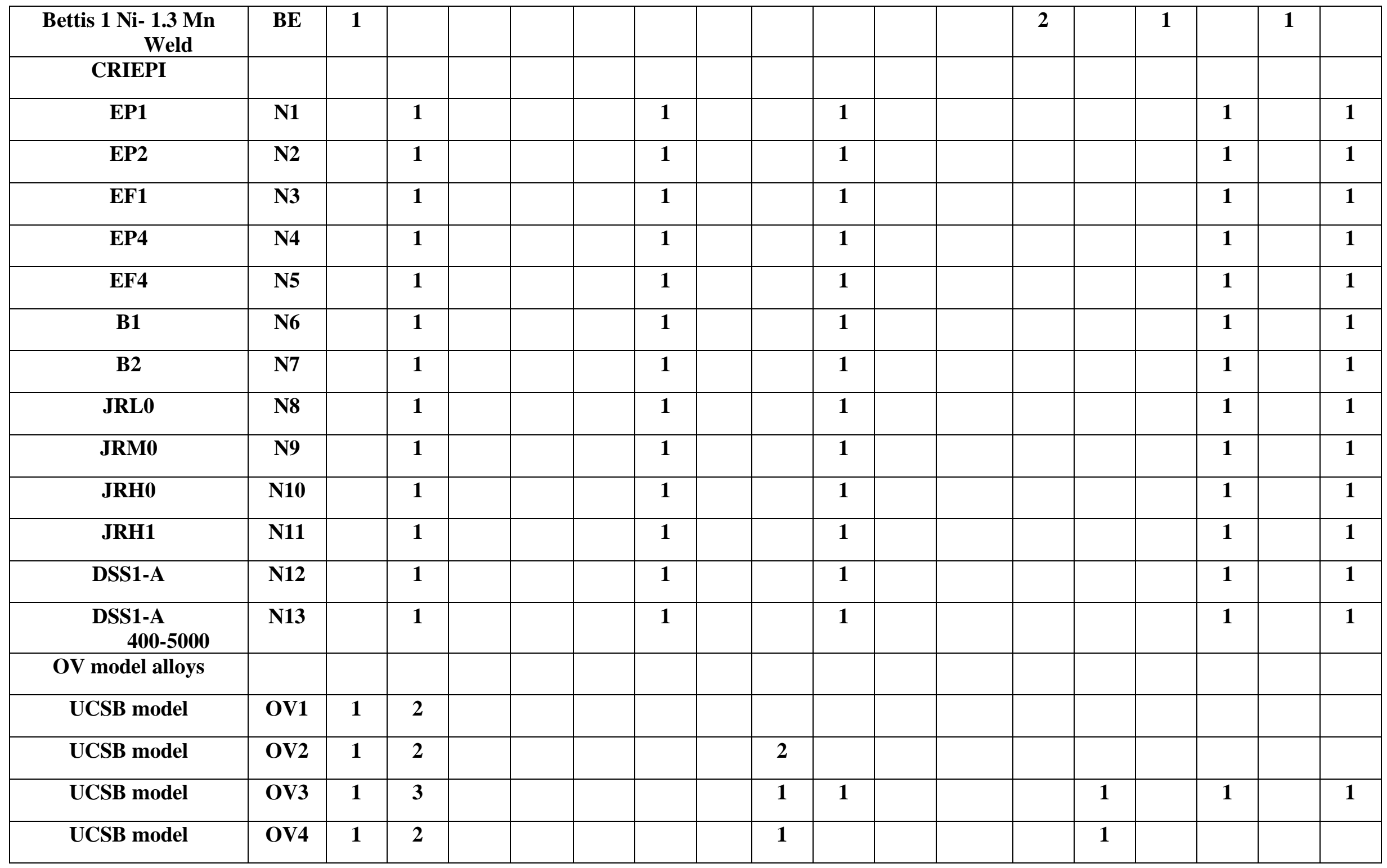




\begin{tabular}{|c|c|c|c|c|c|c|c|c|c|c|c|c|c|c|c|c|c|c|}
\hline UCSB model & OV5 & 1 & 2 & & & & & & 1 & & & & & 1 & & 1 & & 1 \\
\hline UCSB model & OV6 & 1 & 2 & & & & & & 1 & 1 & & & & & & & & \\
\hline UCSB model & OV7 & & 2 & & & & & & & 1 & & & & 1 & & 1 & & 1 \\
\hline UCSB model & OV17 & 1 & 2 & & & & & & & & & & & & & & & \\
\hline UCSB model & OV18 & 1 & 2 & & & & & & & & & & & & & & & \\
\hline UCSB model & OV20 & 1 & 2 & & & & & & & & & & & & & & & \\
\hline Diff Multiple & DM & 1 & & & & & & & 1 & & & & & & & & 1 & \\
\hline & tot & 251 & 69 & 192 & 28 & 263 & 51 & 141 & 274 & 42 & 34 & 17 & 77 & 20 & 78 & 21 & 82 & 21 \\
\hline & All & 166 & & & & & & & & & & & & & & & & \\
\hline & Discs & 124 & & & & & & & & & & & & & & & & \\
\hline & Tens & 367 & & & & & & & & & & & & & & & & \\
\hline & DCT & 45 & & & & & & & & & & & & & & & & \\
\hline & DM & 3 & & & & & & & & & & & & & & & & \\
\hline
\end{tabular}


APPENDIX C. Separate tables for alloys.

Table C.1 Disc Compact Tension (DCT) Specimen Matrix

\begin{tabular}{|c|c|c|c|c|c|c|c|c|c|c|c|c|c|c|c|c|c|c|}
\hline \multirow{2}{*}{ description } & \multirow[b]{2}{*}{ I.D. } & \multicolumn{3}{|c|}{$290 \mathrm{hi}$} & \multirow[b]{2}{*}{ DCT } & \multicolumn{3}{|c|}{290 med } & \multicolumn{3}{|c|}{290 lo } & \multirow[b]{2}{*}{ DCT } & \multirow[b]{2}{*}{ Lg Disc } & \multirow{2}{*}{$\begin{array}{c}250 \\
\text { Sm Disc } \\
\end{array}$} & \multirow[b]{2}{*}{ Lg Disc } & \multirow{2}{*}{\begin{tabular}{|c|}
270 \\
Sm Disc \\
\end{tabular}} & \multirow[b]{2}{*}{ Lg Disc } & \multirow{2}{*}{$\begin{array}{c}310 \\
\text { Sm Disc }\end{array}$} \\
\hline & & Lg Disc & Sm Disc & Tens & & Lg Disc & Sm Disc & tens & Lg Disc & Sm Disc & Tens & & & & & & & \\
\hline \multicolumn{19}{|c|}{ (1) } \\
\hline Pal. B weld & PBW & 3 & & 19 & 14 & & & & & & & & & & & & & \\
\hline UCSB forging ( $\mathrm{C} 17$ as tempered) & XY & 4 & & 18 & 14 & & & & & & & & & & & & & \\
\hline UCSB forging (LP as tempered) & LP & 1 & & & & 2 & & & 4 & & 17 & 17 & & & & & & \\
\hline
\end{tabular}


Table C.2 UCSB CM Alloys

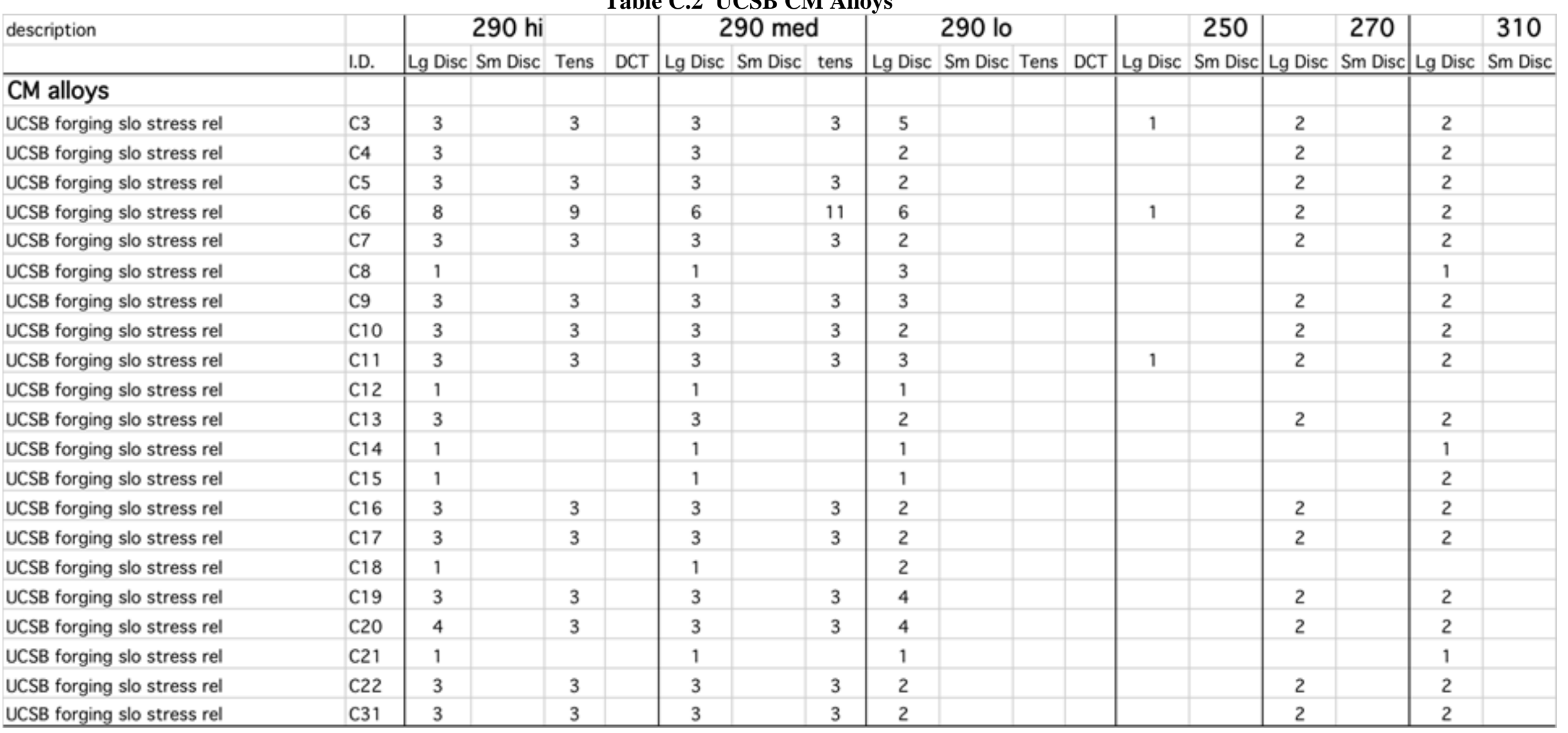


Table C.3 Laval and IVAR Commercial Alloys

\begin{tabular}{|c|c|c|c|c|c|c|c|c|c|c|c|c|c|c|c|c|c|c|}
\hline \multirow{2}{*}{ description } & \multirow{2}{*}{ I.D. } & \multicolumn{3}{|c|}{$290 \mathrm{hi}$} & \multirow{2}{*}{ DCT } & \multicolumn{3}{|c|}{290 med } & \multicolumn{3}{|c|}{$\begin{array}{l}\text { Alloys } \\
290 \text { lo }\end{array}$} & \multirow{2}{*}{ DCT } & \multirow{2}{*}{ Lg Disc } & \multirow{2}{*}{$\begin{array}{c}250 \\
\text { Sm Disc } \\
\end{array}$} & \multirow{2}{*}{ Lg Disc } & \multirow{2}{*}{\begin{tabular}{|c|}
270 \\
Sm Disc \\
\end{tabular}} & \multirow[b]{2}{*}{ Lg Disc } & \multirow{2}{*}{$\begin{array}{c}310 \\
\text { Sm Disc } \\
\end{array}$} \\
\hline & & Lg Disc & Sm Disc & Tens & & Lg Disc & Sm Disc & tens & Lg Disc & Sm Disc & Tens & & & & & & & \\
\hline \multicolumn{19}{|l|}{ Laval alloys } \\
\hline UCSB forging & LA & 1 & & & & 1 & & & 1 & & & & & & & & & \\
\hline UCSB forging & LB & 1 & & 3 & & 1 & & 3 & 1 & & & & 1 & & 1 & & 1 & \\
\hline UCSB forging & LC & 3 & & 4 & & 2 & & 3 & 2 & & & & 1 & & 1 & & 1 & \\
\hline UCSB forging & LD & 3 & & 4 & & 2 & & 3 & 2 & & & & 1 & & 1 & & 1 & \\
\hline UCSB forging & LG & 3 & & 4 & & 2 & & 3 & 2 & & & & & & 1 & & 1 & \\
\hline UCSB forging & LH & 3 & & 3 & & 2 & & 3 & 2 & & & & 1 & & 1 & & 1 & \\
\hline UCSB forging & U & 3 & & 3 & & 2 & & 3 & 2 & & & & & & 1 & & 1 & \\
\hline UCSB forging & LJ & 2 & & 3 & & 2 & & 3 & 2 & & & & & & & & 1 & \\
\hline UCSB forging & LK & 1 & & & & 2 & & 3 & 1 & & & & & & & & & \\
\hline UCSB forging & LO & 1 & & & & 2 & & & 1 & & & & & & & & & \\
\hline \multicolumn{19}{|c|}{ Comm. IVAR alloys } \\
\hline BW A weld & WA & 2 & & 3 & & 2 & & 3 & 2 & & & & & & 1 & & 1 & \\
\hline BW B weld & WB & 2 & & 3 & & 2 & & 3 & 1 & & & & & & 1 & & 1 & \\
\hline BW C weld & WC & 2 & & 3 & & 2 & & 3 & 1 & & & & & & 1 & & 1 & \\
\hline BW 62 weld & W62 & 3 & & 3 & & 2 & & 3 & 2 & & & & & & 1 & & 1 & \\
\hline BW 63 weld & W63 & 3 & & 3 & & 2 & & 3 & 2 & & & & & & 1 & & 1 & \\
\hline BW 65 weld & W65 & 3 & & 3 & & 2 & & 2 & & 1 & & & & 1 & 1 & 1 & & 1 \\
\hline BW 67 weld & W67 & 3 & & 3 & & 2 & & 3 & 2 & & & & & & 1 & & 1 & \\
\hline ORNL 73 weld & W73 & 4 & & 3 & & 2 & & 3 & 2 & & & & & & 1 & & 2 & \\
\hline Midland weld & MW & 3 & & & & 3 & & & 2 & & & & & & 1 & & 1 & \\
\hline ORNL HSSTO2 plate & 02 & 2 & & & & 1 & & & 2 & & & & & & 1 & & 1 & \\
\hline BW A302B plate & 032 & 2 & & & & 2 & & & 2 & & & & & & & & & \\
\hline BW A508 plate & 58 & 3 & & & & 3 & & & 2 & & & & & & & & & \\
\hline JRQ comm plate & Q & 3 & & 3 & & 3 & & 3 & 2 & & & & & & 1 & & 1 & \\
\hline
\end{tabular}


Table C.4 EPRI Alloys

\begin{tabular}{|c|c|c|c|c|c|c|c|c|c|c|c|c|c|c|c|c|c|c|}
\hline & \multirow[b]{3}{*}{ I.D. } & \multirow{2}{*}{\multicolumn{3}{|c|}{290 hi }} & \multirow[b]{3}{*}{ DCT } & \multirow{2}{*}{\multicolumn{3}{|c|}{290 med }} & \multirow{2}{*}{\multicolumn{3}{|c|}{290 lo }} & \multirow[b]{3}{*}{ DCT } & \multirow[b]{3}{*}{ Lg Disc } & \multirow{3}{*}{$\begin{array}{c}250 \\
\text { Sm Disc }\end{array}$} & \multirow[b]{3}{*}{ Lg Disc } & \multirow{3}{*}{\begin{tabular}{|c|}
270 \\
Sm Disc \\
\end{tabular}} & \multirow[b]{3}{*}{ Lg Disc } & \multirow{3}{*}{$\begin{array}{c}310 \\
\text { Sm Disc }\end{array}$} \\
\hline \multirow[t]{2}{*}{ description } & & & & & & & & & & & & & & & & & & \\
\hline & & Lg Disc & Sm Disc & Tens & & Lg Disc & Sm Disc & tens & Lg Disc & Sm Disc & Tens & & & & & & & \\
\hline \multicolumn{19}{|l|}{ EPRI alloys } \\
\hline A 320 B plate & EA & 4 & & & & 3 & & & 1 & & & & & & 1 & & 1 & \\
\hline Linde 0080 wld & EC & 4 & & 3 & & 3 & & 3 & 1 & & & & & & & & & \\
\hline Linde 0090 wld & ED & 2 & & & & 2 & & & 1 & & & & & & & & & \\
\hline A533 B plate $1 \mathrm{bG}$ & E1 & 2 & & & & 3 & & & 3 & & & & & & & & & \\
\hline A533 B plate $1 \mathrm{bJ}$ & E2 & 2 & & & & 3 & & & 3 & & & & & & & & & \\
\hline A533 B plate $1 \mathrm{bN}$ & E3 & 2 & & & & 3 & & & 3 & & & & & & & & & \\
\hline A533 B weld $1 \mathrm{mT}$ & E5 & 2 & & & & 3 & & & 3 & & & & & & & & & \\
\hline A533 B weld $1 \mathrm{mU}$ & E6 & 2 & & & & 3 & & & 3 & & & & & & & & & \\
\hline A533 B weld $1 \mathrm{sX}$ & E7 & 2 & & & & 3 & & & 3 & & & & & & & & & \\
\hline A508-2 plate $2 \mathrm{bA}$ & E8 & 2 & & & & 3 & & & 3 & & & & & & & & & \\
\hline A508-1 plate 5 bA & E9 & 1 & & & & 3 & & & 2 & & & & & & & & & \\
\hline Quad Cit. 1 weld & QC1 & 3 & & 3 & & 2 & & & 3 & & & & & & 1 & & 1 & \\
\hline Quad Cit. 2 weld & QC2 & 2 & & 3 & & 1 & & & & & & & & & 1 & & 1 & \\
\hline Dresden 3 weld & D3 & 3 & & 3 & & 2 & & & 2 & & & & & & 1 & & 1 & \\
\hline Humblt Bay weld & $\mathrm{HB}$ & 2 & & 3 & & 2 & & & 2 & & & & & & 1 & & 1 & \\
\hline Milstone Pt weld & MP & 2 & & 3 & & 2 & & & 1 & & & & & & 1 & & 1 & \\
\hline Tarapur weld & TW & 2 & & & & 2 & & & 2 & & & & & & 1 & & & \\
\hline FRG 8460 & FD & & & & & & & & 1 & & & & & & 1 & & 1 & \\
\hline FRG 8240 & $\mathrm{FE}$ & 1 & & & & & & & 1 & & & & & & 1 & & 1 & \\
\hline FRG 8310 & $F M$ & & & & & & & & 1 & & & & & & 1 & & 1 & \\
\hline
\end{tabular}


Table C.5 ORNL Commercial Surveillance Materials

\begin{tabular}{|c|c|c|c|c|c|c|c|c|c|c|c|c|c|c|c|c|c|c|}
\hline \multirow[t]{2}{*}{ description } & \multirow[b]{2}{*}{ I.D. } & \multicolumn{3}{|c|}{$290 \mathrm{hi}$} & \multirow[b]{2}{*}{ DCT } & \multicolumn{3}{|c|}{290 med } & \multicolumn{3}{|c|}{290 lo } & \multirow[b]{2}{*}{ DCT } & \multirow{2}{*}{ Lg Disc } & \multirow{2}{*}{$\begin{array}{c}250 \\
\text { Sm Disc } \\
\end{array}$} & \multirow[b]{2}{*}{ Lg Disc } & \multirow{2}{*}{\begin{tabular}{c|}
270 \\
Sm Disc \\
\end{tabular}} & \multirow[b]{2}{*}{ Lg Disc } & \multirow{2}{*}{$\begin{array}{r}310 \\
\text { Sm Disc }\end{array}$} \\
\hline & & Lg Disc & Sm Disc & Tens & & Lg Disc & Sm Disc & tens & Lg Disc & Sm Disc & Tens & & & & & & & \\
\hline \multicolumn{19}{|l|}{ ORNL surv. alloys } \\
\hline Farley 1 weld & F1W & 4 & & 3 & & 2 & & 3 & 3 & & & & & & 1 & & 1 & \\
\hline Farley 2 plate & F2B & & 2 & 3 & & & 2 & 3 & & 1 & & & & 1 & & 1 & & 1 \\
\hline Kewaunee plate & KP & 4 & & 3 & & 3 & & 4 & 4 & & & & 1 & & 2 & & 1 & \\
\hline Maine Yankee weld & MY & & 3 & & & & 3 & & & 1 & & & & 1 & & 1 & & 1 \\
\hline Beaver Valley 2 Plate & BV & 4 & & 3 & & 3 & & 3 & 4 & & & & 1 & & 1 & & 1 & \\
\hline Kewaunee Weld & KW & 4 & & 3 & & 3 & & 3 & 5 & & 2 & & 1 & & 2 & & 1 & \\
\hline Farley 2 wld & F2W & & 3 & 3 & & & 3 & 3 & & 1 & & & & 1 & & 1 & & 1 \\
\hline VC SUMMER WELD & VCW & & 3 & 3 & & & 3 & 3 & & 1 & & & & 1 & & 1 & & 1 \\
\hline Turkey Point Weld & TP & 3 & & 3 & & & 3 & 3 & 3 & & & & & & 1 & & 1 & \\
\hline
\end{tabular}


Table C.6 Rolls-Royce Alloys (1)

description \begin{tabular}{l|l} 
& Table C.6 Rolls-Royce \\
$290 \mathrm{hi}$ & $290 \mathrm{med}$
\end{tabular} 290 lo

Rolls Royce alloy L2385 Rolls Royce alloy L2402 Rolls Royce alloy L2403 Rolls Royce alloy L2404 Rolls Royce alloy L2405 Rolls Royce alloy L2406 Rolls Royce alloy L2407 I.D. Lg Disc Sm Disc

Rolls Royce alloy L2410 Rolls Royce alloy L2414 Rolls Royce alloy L2384 Rolls Royce alloy L2408 Rolls Royce alloy L2409 Rolls Royce alloy L2415 Rolls Royce alloy L2416 Rolls Royce alloy L2417 Rolls Royce alloy L2418 Rolls Royce alloy L2436

Rolls Royce alloy L2435 Rolls Royce alloy L2411 Rolls Royce alloy L2421 Rolls Royce alloy L2412 Rolls Royce alloy L2413 Rolls Royce alloy L2433 Rolls Royce alloy L2397 Rolls Royce alloy L2434

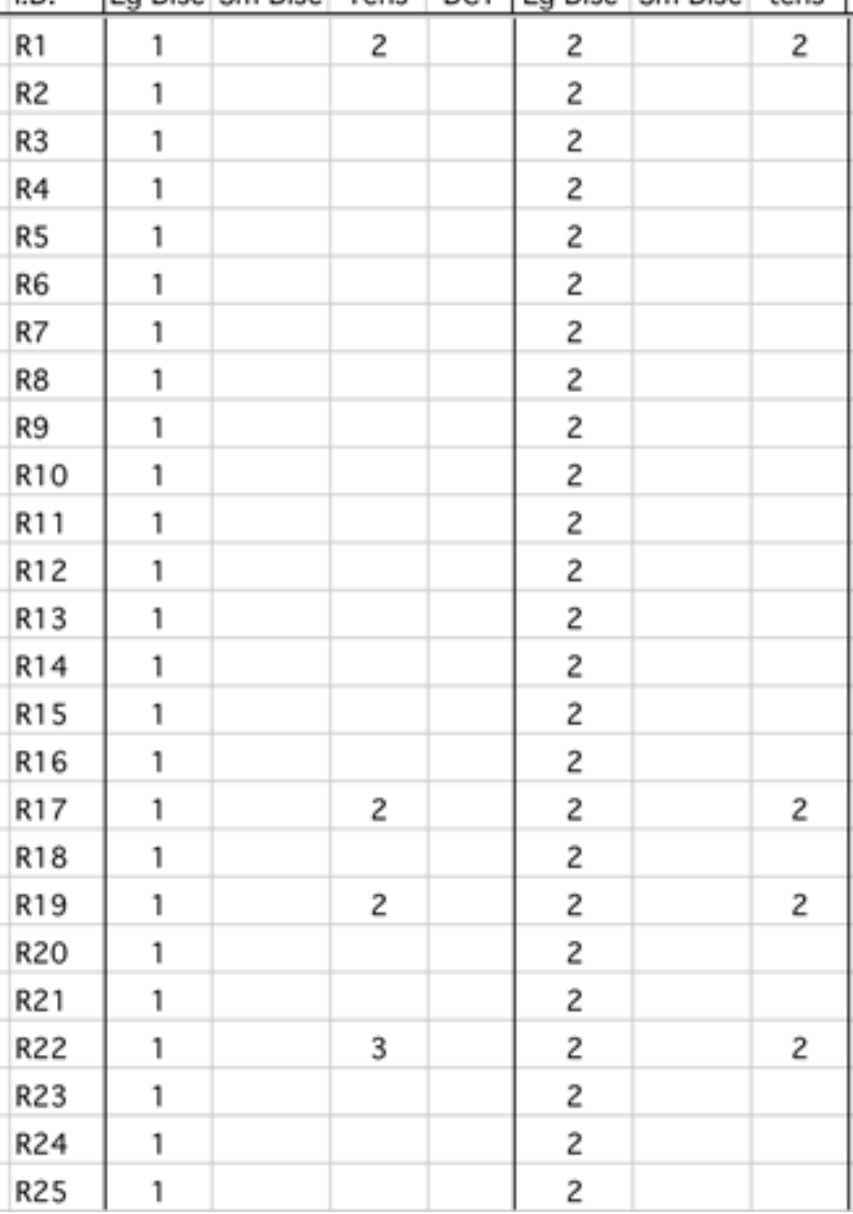

\begin{tabular}{|c|c|}
\hline 3 & 2 \\
\hline 2 & \\
\hline 2 & \\
\hline 2 & \\
\hline 2 & \\
\hline 2 & \\
\hline 2 & \\
\hline 2 & \\
\hline 2 & \\
\hline 3 & \\
\hline 2 & \\
\hline 2 & \\
\hline 2 & \\
\hline 2 & \\
\hline 2 & \\
\hline 2 & \\
\hline 2 & 2 \\
\hline 2 & \\
\hline 3 & 2 \\
\hline 2 & \\
\hline 2 & \\
\hline 3 & 1 \\
\hline 2 & \\
\hline 2 & \\
\hline 2 & \\
\hline
\end{tabular}

\begin{tabular}{|c|c|c|c|c|c|}
\hline Lg Disc & Sm Disc & Lg Disc & Sm Disc & Lg Disc & Sm Disc \\
\hline 1 & & 1 & & 2 & \\
\hline 1 & & & & & \\
\hline 1 & & & & & \\
\hline 1 & & & & & \\
\hline 1 & & & & & \\
\hline 1 & & & & & \\
\hline 1 & & & & & \\
\hline 1 & & & & & \\
\hline 1 & & & & & \\
\hline 1 & & 1 & & 1 & \\
\hline 1 & & & & & \\
\hline 1 & & & & & \\
\hline 1 & & & & & \\
\hline 1 & & & & & \\
\hline 1 & & & & & \\
\hline 1 & & & & & \\
\hline 1 & & & & & \\
\hline 1 & & & & & \\
\hline 1 & & 1 & & 1 & \\
\hline 1 & & & & & \\
\hline 1 & & & & & \\
\hline 1 & & 1 & & 1 & \\
\hline 1 & & & & & \\
\hline 1 & & & & & \\
\hline 1 & & & & & \\
\hline
\end{tabular}


Table C.7 Rolls-Royce Alloys (2)

description 290 hi Table C.7 Rolls-Royce

290 lo

250

270

310

\begin{tabular}{|c|c|c|c|c|c|c|c|c|c|c|c|c|c|c|c|c|c|c|}
\hline & I.D. & Lg Disc & Sm Disc & Tens & DCT & Lg Disc & Sm Disc & tens & Lg Disc & Sm Disc & Tens & DCT & Lg Disc & Sm Disc & Lg Disc & Sm Disc & Lg Disc & Sm Disc \\
\hline Rolls Royce alloy L2386 & R26 & 1 & & 2 & & 2 & & 2 & 3 & & 2 & & 1 & & 1 & & 1 & \\
\hline Rolls Royce alloy L2423 & R27 & 1 & & 2 & & 2 & & 2 & 2 & & 2 & & 1 & & & & & \\
\hline Rolls Royce alloy L2422 & R28 & 1 & & & & 2 & & & 2 & & & & 1 & & & & & \\
\hline Rolls Royce alloy L2424 & R29 & 1 & & & & 2 & & & 2 & & & & 1 & & & & & \\
\hline Rolls Royce alloy L2429 & R30 & 1 & & & & 2 & & & 2 & & & & 1 & & 1 & & 1 & \\
\hline Rolls Royce alloy L2430 & R31 & 1 & & & & 2 & & & 3 & & & & 1 & & 1 & & 1 & \\
\hline Rolls Royce alloy L2398 & R32 & 1 & & & & 2 & & & 2 & & & & 1 & & & & & \\
\hline Rolls Royce alloy L2420 & R33 & 1 & & & & 2 & & & 2 & & & & 1 & & & & & \\
\hline Rolls Royce alloy L2419 & R34 & 1 & & & & 2 & & & 3 & & & & 1 & & 1 & & 1 & \\
\hline Rolls Royce alloy L2399 & R35 & 1 & & 2 & & 2 & & 2 & 3 & & 2 & & 1 & & & & & \\
\hline Rolls Royce alloy L2425 & R36 & 1 & & & & 2 & & & 2 & & & & 1 & & & & & \\
\hline Rolls Royce alloy L2426 & R37 & 1 & & & & 2 & & & 2 & & & & 1 & & & & & \\
\hline Rolls Royce alloy L2427 & R38 & 1 & & & & 2 & & & 2 & & & & 1 & & & & & \\
\hline Rolls Royce alloy L2400 & R39 & 1 & & 2 & & 2 & & 2 & 3 & & 2 & & 1 & & 1 & & 1 & \\
\hline Rolls Royce alloy L2428 & R40 & 1 & & & & 2 & & & 2 & & & & 1 & & & & & \\
\hline Rolls Royce alloy L2431 & R41 & 1 & & & & 2 & & & 2 & & & & 1 & & & & & \\
\hline Rolls Royce alloy L2432 & R42 & 1 & & & & 2 & & & 2 & & & & 1 & & & & & \\
\hline Rolls Royce alloy L2437 & R43 & 1 & & & & 2 & & & 2 & & & & 1 & & & & & \\
\hline Rolls Royce alloy L2438 & R44 & 1 & & & & 2 & & & 2 & & & & 1 & & & & & \\
\hline Rolls Royce alloy L2439 & R45 & 1 & & & & 2 & & & 2 & & & & 1 & & & & & \\
\hline Rolls Royce alloy L2401 & R46 & 1 & & & & 2 & & & 2 & & & & 1 & & & & & \\
\hline Rolls Royce alloy L2440 & R47 & 1 & & & & 2 & & & 2 & & & & 1 & & & & & \\
\hline Rolls Royce alloy L2444 & R48 & 1 & & & & 2 & & & 2 & & & & 1 & & & & & \\
\hline Rolls Royce alloy L2442 & R49 & 1 & & & & 2 & & & 2 & & & & 1 & & & & & \\
\hline Rolls Royce alloy L2443 & R50 & 1 & & & & 2 & & & 2 & & & & 1 & & & & & \\
\hline
\end{tabular}


Table C.8 Rolls-Royce Alloys (3)

\begin{tabular}{|c|c|c|c|c|c|c|c|c|c|c|c|c|c|c|c|c|c|c|}
\hline & \multirow[b]{3}{*}{ I.D. } & \multirow{2}{*}{\multicolumn{3}{|c|}{290 hi }} & \multirow{2}{*}{\multicolumn{4}{|c|}{290 med }} & \multirow{2}{*}{\multicolumn{3}{|c|}{290 lo }} & \multirow[b]{3}{*}{ DCT } & \multirow[b]{3}{*}{ Lg Disc } & \multirow{3}{*}{\begin{tabular}{|c|}
250 \\
Sm Disc
\end{tabular}} & \multirow[b]{3}{*}{ Lg Disc } & \multirow{3}{*}{\begin{tabular}{|c|}
270 \\
Sm Disc
\end{tabular}} & \multirow[b]{3}{*}{ Lg Disc } & \multirow{3}{*}{$\begin{array}{c}310 \\
\text { Sm Disc }\end{array}$} \\
\hline \multirow[t]{2}{*}{ description } & & & & & & & & & & & & & & & & & & \\
\hline & & Lg Disc & Sm Disc & Tens & DCT & Lg Disc & Sm Disc & tens & Lg Disc & Sm Disc & Tens & & & & & & & \\
\hline Rolls Royce WP weld & RX1 & & 4 & & & & 4 & & & 1 & & & & 1 & & & & \\
\hline Rolls Royce WK weld & RX2 & & 2 & & & & 2 & & & 2 & & & & 1 & & & & \\
\hline Rolls Royce WV Weld & RX3 & & 2 & & & & 2 & & & 3 & & & & 1 & & & & \\
\hline Rolls Royce SP weld & RX4 & & 2 & & & & 2 & & & 2 & & & & 1 & & & & \\
\hline Rolls Royce SL weld & RXS & & 2 & & & & 2 & & & 2 & & & & 1 & & & & \\
\hline Rolls Royce SJ weld & RX6 & & 2 & & & & 2 & & & 2 & & & & 1 & & & & \\
\hline Rolls Royce PL plate & RX7 & & 2 & & & & 2 & & & 2 & & & & 1 & & & & \\
\hline Rolls Royce PS plate & RX8 & & 2 & & & & 2 & & & 2 & & & & 1 & & & & \\
\hline Rolls Royce FT2 forging & RX9 & & 2 & & & & 2 & & & 1 & & & & 1 & & & & \\
\hline Rolls Royce WT weld & $R \times 10$ & 1 & & & & 1 & & & 1 & & & & 1 & & & & & \\
\hline Rolls Royce FT5 forging & RX11 & & 2 & & & & 2 & & & 1 & & & & 1 & & & & \\
\hline Rolls Royce FK forging & RX12 & & 2 & & & & 2 & & & 3 & & & & 1 & & & & \\
\hline \multicolumn{19}{|l|}{ RR Heat trt } \\
\hline RR40 $650^{\circ} \mathrm{C} / 5 \mathrm{hr}$ & RH1 & 1 & & & & 1 & & & 1 & & & & 1 & & & & & \\
\hline RR40 $625^{\circ} \mathrm{C} / 5 \mathrm{hr}$ & RH2 & 1 & & & & 1 & & & 1 & & & & 1 & & & & & \\
\hline RR22 $600^{\circ} \mathrm{C} / 48 \mathrm{hr}$ & RH3 & 1 & & & & 1 & & & 1 & & & & 1 & & & & & \\
\hline RR23 $600^{\circ} \mathrm{C} / 48 \mathrm{hr}$ & $\mathrm{RH} 4$ & 1 & & & & 1 & & & 1 & & & & 1 & & & & & \\
\hline RR26 $600^{\circ} \mathrm{C} / 48 \mathrm{hr}$ & RH5 & 1 & & & & 1 & & & 1 & & & & 1 & & & & & \\
\hline RR27 $600^{\circ} \mathrm{C} / 48 \mathrm{hr}$ & RH6 & 1 & & & & 1 & & & 1 & & & & 1 & & & & & \\
\hline
\end{tabular}


Table C.9 Bettis and CRIEPI Alloys

\begin{tabular}{|c|c|c|c|c|c|c|c|c|c|c|c|c|c|c|c|c|c|c|}
\hline \multirow{3}{*}{ description } & \multirow[b]{3}{*}{ I.D. } & & & & & & & & \multirow{2}{*}{\multicolumn{3}{|c|}{290 lo }} & \multirow[b]{3}{*}{ DCT } & \multirow[b]{3}{*}{ Lg Disc } & \multirow{3}{*}{$\begin{array}{c}250 \\
\text { Sm Disc } \\
\end{array}$} & \multirow[b]{3}{*}{ Lg Disc } & \multirow{3}{*}{$\begin{array}{c}270 \\
\text { Sm Disc } \\
\end{array}$} & \multirow[b]{3}{*}{ Lg Disc } & \multirow{3}{*}{$\begin{array}{r}310 \\
\text { Sm Disc }\end{array}$} \\
\hline & & & $290 \mathrm{hi}$ & & & & $290 \mathrm{me}$ & & & & & & & & & & & \\
\hline & & Lg Disc & Sm Disc & Tens & DCT & Lg Disc & Sm Disc & tens & Lg Disc & Sm Disc & Tens & & & & & & & \\
\hline \multicolumn{19}{|l|}{ Bettis } \\
\hline Bettis A508 Gr 4N (207N947) & BA & 1 & & & & & & & & & & & 2 & & 1 & & 1 & \\
\hline Bettis A508 Gr 4N (124S285) & BB & 1 & & & & & & & & & & & 2 & & 1 & & 1 & \\
\hline Bettis Superclean A508 Gr4N (1) & BC & 1 & & & & & & & & & & & 2 & & 1 & & 1 & \\
\hline Bettis Superclean A508 GR4N (2) & BD & 1 & & & & & & & & & & & 2 & & 1 & & 1 & \\
\hline Bettis $1 \mathrm{Ni}-1.3 \mathrm{Mn}$ Weld & $\mathrm{BE}$ & 1 & & & & & & & & & & & 2 & & 1 & & 1 & \\
\hline \multicolumn{19}{|l|}{ CRIEPI } \\
\hline EP1 & N1 & & 1 & & & & 1 & & & 1 & & & & & & 1 & & 1 \\
\hline EP2 & N2 & & 1 & & & & 1 & & & 1 & & & & & & 1 & & 1 \\
\hline EF1 & N3 & & 1 & & & & 1 & & & 1 & & & & & & 1 & & 1 \\
\hline EP4 & N4 & & 1 & & & & 1 & & & 1 & & & & & & 1 & & 1 \\
\hline EF4 & N5 & & 1 & & & & 1 & & & 1 & & & & & & 1 & & 1 \\
\hline B1 & N6 & & 1 & & & & 1 & & & 1 & & & & & & 1 & & 1 \\
\hline B2 & N7 & & 1 & & & & 1 & & & 1 & & & & & & 1 & & 1 \\
\hline JRLO & N8 & & 1 & & & & 1 & & & 1 & & & & & & 1 & & 1 \\
\hline JRMO & N9 & & 1 & & & & 1 & & & 1 & & & & & & 1 & & 1 \\
\hline JRHO & N10 & & 1 & & & & 1 & & & 1 & & & & & & 1 & & 1 \\
\hline JRH1 & N11 & & 1 & & & & 1 & & & 1 & & & & & & 1 & & 1 \\
\hline DSS1-A & N12 & & 1 & & & & 1 & & & 1 & & & & & & 1 & & 1 \\
\hline DSS1-A 400-5000 & N13 & & 1 & & & & 1 & & & 1 & & & & & & 1 & & 1 \\
\hline
\end{tabular}


Table C.10 Model Alloys and Diffusion Multiples

\begin{tabular}{|c|c|c|c|c|c|c|c|c|c|c|c|c|c|c|c|c|c|c|}
\hline & & \multirow{2}{*}{\multicolumn{3}{|c|}{$290 \mathrm{hi}$}} & \multirow[b]{3}{*}{ DCT } & \multirow{2}{*}{\multicolumn{3}{|c|}{290 med }} & \multirow{2}{*}{\multicolumn{3}{|c|}{290 lo }} & \multirow[b]{3}{*}{ DCT } & \multirow[b]{3}{*}{ Lg Disc } & \multirow{3}{*}{$\begin{array}{c}250 \\
\text { Sm Disc } \\
\end{array}$} & \multirow[b]{3}{*}{ Lg Disc } & \multirow{3}{*}{\begin{tabular}{|c|}
270 \\
Sm Disc \\
\end{tabular}} & & \\
\hline \multirow[t]{2}{*}{ description } & \multirow[b]{2}{*}{ I.D. } & & & & & & & & & & & & & & & & \multirow[b]{2}{*}{ Lg Disc } & \multirow{2}{*}{$\begin{array}{c}310 \\
\text { Sm Disc }\end{array}$} \\
\hline & & Lg Disc & Sm Disc & Tens & & Lg Disc & Sm Disc & tens & Lg Disc & Sm Disc & Tens & & & & & & & \\
\hline \multicolumn{19}{|c|}{ OV model alloys } \\
\hline UCSB model & OV1 & 1 & 2 & & & & & & & & & & & & & & & \\
\hline UCSB model & ov2 & 1 & 2 & & & & & & 2 & & & & & & & & & \\
\hline UCSB model & OV3 & 1 & 3 & & & & & & 1 & 1 & & & & 1 & & 1 & & 1 \\
\hline UCSB model & OV4 & 1 & 2 & & & & & & 1 & & & & & 1 & & & & \\
\hline UCSB model & OV5 & 1 & 2 & & & & & & 1 & & & & & 1 & & 1 & & 1 \\
\hline UCSB model & ov6 & 1 & 2 & & & & & & 1 & 1 & & & & & & & & \\
\hline UCSB model & OV7 & & 2 & & & & & & & 1 & & & & 1 & & 1 & & 1 \\
\hline UCSB model & ov17 & 1 & 2 & & & & & & & & & & & & & & & \\
\hline UCSB model & OV18 & 1 & 2 & & & & & & & & & & & & & & & \\
\hline UCSB model & ov20 & 1 & 2 & & & & & & & & & & & & & & & \\
\hline \multirow[t]{2}{*}{ Diff Multiple } & DM & 1 & & & & & & & 1 & & & & & & & & 1 & \\
\hline & & & & & & & & & & & & & & & & & & \\
\hline
\end{tabular}




\section{APPENDIX D. Preliminary Schedule for post-irradiation examination of ATR-2 experiment.}

POST-IRRADIATION EVALUATION-UCSB ATR-2 IRRADIATION EXPERIMENT

\begin{tabular}{|c|c|c|c|c|c|c|c|c|c|c|c|c|c|c|c|c|c|c|}
\hline Task & Subtask & Task Title & $\begin{array}{l}\text { FY14- } \\
\text { Qtr1 }\end{array}$ & $\begin{array}{l}\text { FY14- } \\
\text { Qtr2 }\end{array}$ & $\begin{array}{l}\text { FY14- } \\
\text { Qtr3 }\end{array}$ & $\begin{array}{l}\text { FY14- } \\
\text { Qtr4 }\end{array}$ & $\begin{array}{l}\text { FY15- } \\
\text { Qtr1 }\end{array}$ & $\begin{array}{l}\text { FY15- } \\
\text { Qtr2 }\end{array}$ & $\begin{array}{l}\text { FY15- } \\
\text { Qtr3 }\end{array}$ & $\begin{array}{l}\text { FY15- } \\
\text { Qtr4 }\end{array}$ & $\begin{array}{l}\text { FY16- } \\
\text { Qtr1 }\end{array}$ & $\begin{array}{l}\text { FY16- } \\
\text { Qtr2 }\end{array}$ & $\begin{array}{l}\text { FY16- } \\
\text { Qtr3 }\end{array}$ & $\begin{array}{l}\text { FY16- } \\
\text { Qtr4 }\end{array}$ & $\begin{array}{l}\text { FY17- } \\
\text { Qtr1 }\end{array}$ & $\begin{array}{l}\text { FY17- } \\
\text { Qtr2 }\end{array}$ & $\begin{array}{l}\text { FY17- } \\
\text { Qtr3 }\end{array}$ & $\begin{array}{l}\text { FY17- } \\
\text { Qtr4 }\end{array}$ \\
\hline \multirow[t]{6}{*}{1} & & PIE Plan development & & & & & & & & & & & & & & & & \\
\hline & 1.1 & Preliminary palnning & & & & & & & & & & & & & & & & \\
\hline & 1.2 & Discussions with UCSB & & & & & & & & & & & & & & & & \\
\hline & 1.3 & 3 Discussions with INL & & & & & & & & & & & & & & & & \\
\hline & 1.4 & 4 Discussions with ORNL hot cells & & & & & & & & & & & & & & & & \\
\hline & & & & & & & & & & & & & & & & & & \\
\hline \multirow[t]{6}{*}{2} & & Shipment of Capsule & & & & & & & & & & & & & & & & \\
\hline & 2.1 & Ship cask to INL & & & & & & & & & & & & & & & & \\
\hline & 2.2 & \multirow{2}{*}{$\begin{array}{l}\text { Ship cask to ORNL } \\
\text { Receipt of cask at ORNL-IFEL }\end{array}$} & & & & & & & & & & & & & & & & \\
\hline & 2.3 & & & & & & & & & & & & & & & & & \\
\hline & & & & & & & & & & & & & & & & & & \\
\hline & & & & & & & & & & & & & & & & & & \\
\hline \multirow[t]{6}{*}{3} & & Dissassemly of capsule in IFEL & & & & & & & & & & & & & & & & \\
\hline & 3.1 & $\begin{array}{l}\text { Development of dissassembly plan } \\
\text { Dissassemly of capsule, }\end{array}$ & & & & & & & & & & & & & & & & \\
\hline & 3.2 & identification of subcapsules & & & & & & & & & & & & & & & & \\
\hline & 3.3 & Shipment of subcpsules to IMET & & & & & & & & & & & & & & & & \\
\hline & & & & & & & & & & & & & & & & & & \\
\hline & & $\begin{array}{l}\text { Disassembly of subcapsules in } \\
\text { IMET }\end{array}$ & & & & & & & & & & & & & & & & \\
\hline & & $\begin{array}{l}1 \text { Receipt of subcapsule cask at } \\
\text { ORNL-IMET }\end{array}$ & & & & & & & & & & & & & & & & \\
\hline & 4.2 & $\begin{array}{l}\text { Development of subcapsule } \\
\text { dissassembly plan }\end{array}$ & & & & & & & & & & & & & & & & \\
\hline & 4.3 & $\begin{array}{l}3 \text { Dissassembly of subcapsules, } \\
\text { identification and packaging of } \\
\text { specimens }\end{array}$ & & & & & & & & & & & & & & & & \\
\hline & 4.4 & 4 Shipment of specimens to LAMDA & & & & & & & & & & & & & & & & \\
\hline & 4.4 & Shipment of dosimeters to IFEL & & & & & & & & & & & & & & & & \\
\hline & 4.6 & $\begin{array}{l}\text { Shipment of specimens to other } \\
\text { organizations }\end{array}$ & & & & & & & & & & & & & & & & \\
\hline & & & & & & & & & & & & & & & & & & \\
\hline
\end{tabular}




\section{POST-IRRADIATION EVALUATION-UCSB ATR-2 IRRADIATION EXPERIMENT}

Activities in LAMDA/Hot Cells

5.1 Tensile tests (367)

5.2 Microhardness tests (TBD)

5.3 Shear punch tests (500)

5.4 Fracture toughness tests (45)

$5.5 \mathrm{FIB}$ and prepare atom probe samples (TBD)

5.6 Prepare SANS, SAXS samples (TBD)

5.7 Prepare TEM samples(TBD)

Microstructural examination and annealing studies

6

\begin{tabular}{|c|c|c|c|c|c|c|c|c|c|c|c|c|c|c|c|}
\hline $\begin{array}{l}\text { FY14- } \\
\text { Qtr1 }\end{array}$ & $\begin{array}{l}\text { FY14- } \\
\text { Qtr2 }\end{array}$ & $\begin{array}{l}\text { FY14- } \\
\text { Qtr3 }\end{array}$ & $\begin{array}{l}\text { FY14- } \\
\text { Qtr4 }\end{array}$ & $\begin{array}{l}\text { FY15- } \\
\text { Qtr1 }\end{array}$ & $\begin{array}{l}\text { FY15- } \\
\text { Qtr2 }\end{array}$ & $\begin{array}{l}\text { FY15- } \\
\text { Qtr3 }\end{array}$ & $\begin{array}{l}\text { FY15- } \\
\text { Qtr4 }\end{array}$ & $\begin{array}{l}\text { FY16- } \\
\text { Qtr1 }\end{array}$ & $\begin{array}{l}\text { FY16- } \\
\text { Qtr2 }\end{array}$ & $\begin{array}{l}\text { FY16- } \\
\text { Qtr3 }\end{array}$ & $\begin{array}{l}\text { FY16- } \\
\text { Qtr4 }\end{array}$ & $\begin{array}{l}\text { FY17- } \\
\text { Qtr1 }\end{array}$ & $\begin{array}{l}\text { FY17- } \\
\text { Qtr2 }\end{array}$ & $\begin{array}{l}\text { FY17- } \\
\text { Qtr3 }\end{array}$ & $\begin{array}{l}\text { FY17- } \\
\text { Qtr4 }\end{array}$ \\
\hline & & & & & & & & & & & & & & & \\
\hline & & & & & & & & & & & & & & & \\
\hline & & & & & & & & & & & & & & & \\
\hline & & & & & & & & & & & & & & & \\
\hline & & & & & & & & & & & & & & & \\
\hline & & & & & & & & & & & & & & & \\
\hline & & & & & & & & & & & & & & & \\
\hline & & & & & & & & & & & & & & & \\
\hline & & & & & & & & & & & & & & & \\
\hline & & & & & & & & & & & & & & & \\
\hline & & & & & & & & & & & & & & & \\
\hline & & & & & & & & & & & & & & & \\
\hline & & & & & & & & & & & & & & & \\
\hline & & & & & & & & & & & & & & & \\
\hline & & & & & & & & & & & & & & & \\
\hline & & & & & & & & & & & & & & & \\
\hline & & & & & & & & & & & & & & & \\
\hline & & & & & & & & & & & & & & & \\
\hline & & & & & & & & & & & & & & & \\
\hline & & & & & & & & & & & & & & & \\
\hline & & & & & & & & & & & & & & & \\
\hline & & & & & & & & & & & & & & & \\
\hline & & & & & & & & & & & & & & & \\
\hline & & & & & & & & & & & & & & & \\
\hline & & & & & & & & & & & & & & & \\
\hline & & & & & & & & & & & & & & & \\
\hline & & & & & & & & & & & & & & & \\
\hline & & & & & & & & & & & & & & & \\
\hline & & & & & & & & & & & & & & & \\
\hline & & & & & & & & & & & & & & & \\
\hline & & & & & & & & & & & & & & & \\
\hline
\end{tabular}

8.1 Data Analysis

8.2 Progress reports

2 Small angle neutron scattering

(TBD)

(TBD)

6.4 Annealing studies

7 Dosimetric assessments

7.1 Dosimeter counting

7.2 Dosimetric analysis

$8 \quad$ Data Analysis and reporting 